\title{
فرص ومعوقات تطبيق منهجية الكايزن في ضوء تصورات أعضاء هيئة التدريس بجامعة المجمعة
}

\author{
د/ عاطف محمد عبد الباري مبروك \\ أستاذ مساعد إدارة الأعمال بجامعة المجمعة بكلية العلوم والدراسات الإنسانية برماح
}

بريد الكتروني: a.mabrook@mu.edu.sa

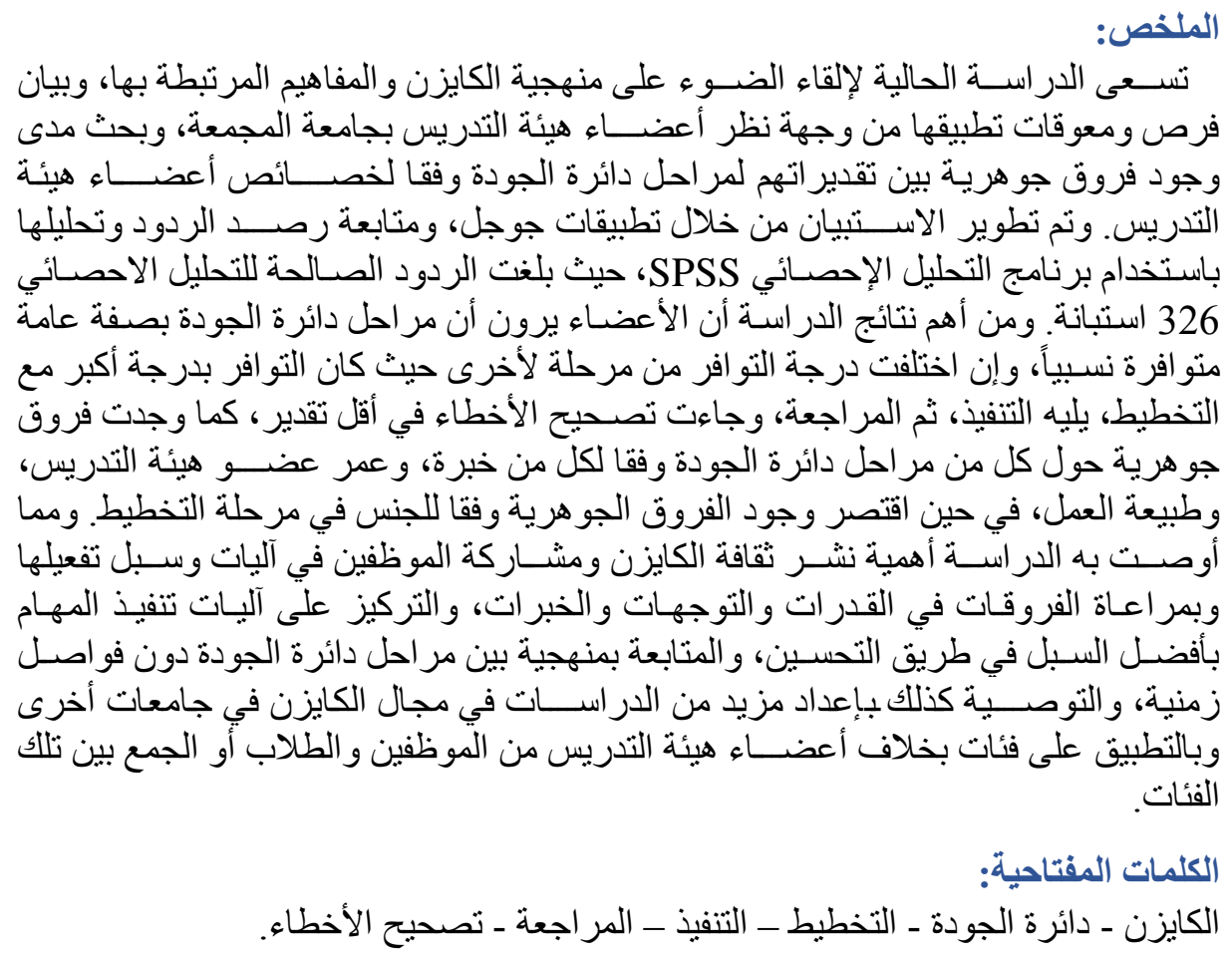

\section{Abstract:}

The current study seeks to shed light on the Kaizen methodology and related concepts, and to identify the opportunities and obstacles of their application from the viewpoint of the faculty members in Majmaah University. The questionnaire was developed through Google applications, and follow-up monitoring and analysis of responses using SPSS, where the responses valid for statistical analysis were 326 questionnaires.

The most important results of the study is that the assessment of the members about the phases of the quality circle in general is relatively 
medium, although the highest concentration with planning and then implementation, then review, and the correction of errors at the least, Substantial differences were found between the estimates of members on each stage of the quality circle according to the experience and age of the faculty member and the nature of the work, while the existence of gender differences was limited to the planning stage.

The most important recommendations of the study are: spreading the culture of Kaizen and the participation of employees in the mechanisms and means of activating them and taking into account the differences in abilities, attitudes and experiences, focusing on the mechanisms of implementing the tasks in the best way in the way of improvement, follow-up methodically between the stages of the quality department without time intervals, and preparing further studies in field of Kaizen at another universities and applying them to categories other than faculty members of employees and students or to mix those categories.

key words:

Execution - Auditing - Correcting Errors- Kaizen- Planning- Quality

Circuits.

$$
\begin{aligned}
& \text { مشكلة الار اسية }
\end{aligned}
$$

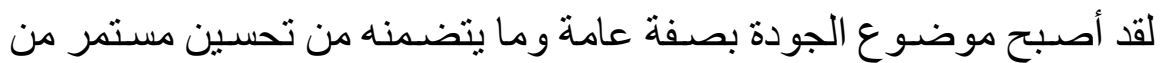

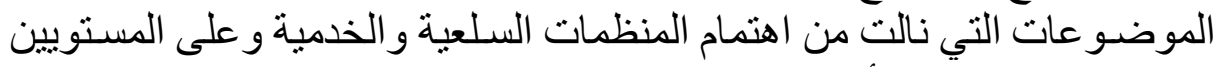

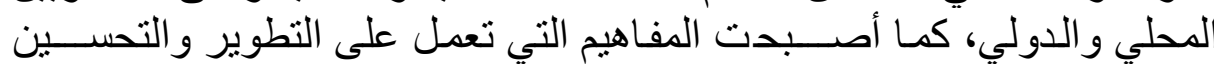

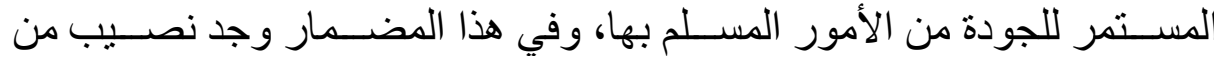

$$
\begin{aligned}
& \text { الاهتمام نحو التوجه للمنهجية اليابانية المسماة بالكايزن. } \\
& \text { وفي هذا الإطار بينت كثير من الدر اســات ضـــرورة نشــر ثقافة الكايزن في }
\end{aligned}
$$

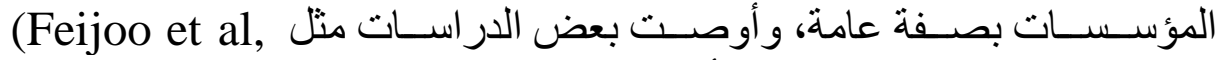

$$
\begin{aligned}
& \text { (Joshi, 2013) (2014) بتبني أسـلوب الكايزن وتطبيقه في مؤسـسـات التعليم } \\
& \text { العالي، حيث تعول المجتمعات في تحقيق طموحاتها في ظل التي التوجهات الحديثة فئنة }
\end{aligned}
$$

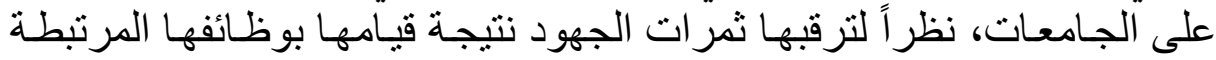

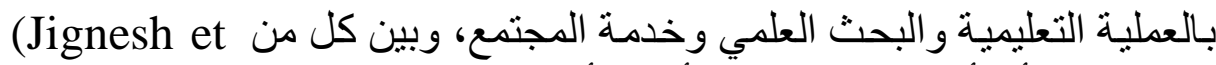

$$
\begin{aligned}
& \text { al, 2014) }
\end{aligned}
$$

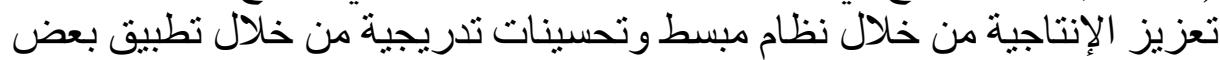

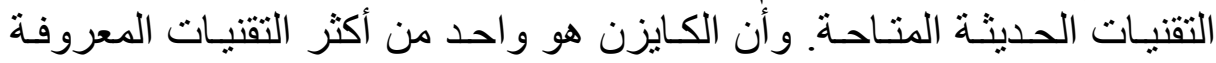

$$
\begin{aligned}
& \text { بالتطور المستمر. حيث أن التطبيق الفعال للكايزن يؤدي إلى نجاح ونمو المنظمة. }
\end{aligned}
$$


وقد أنثـار (Swafy \& Ghatass, 2003) إلى وجود اتجاه عام في أنظمة

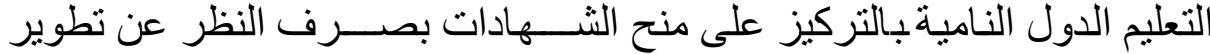

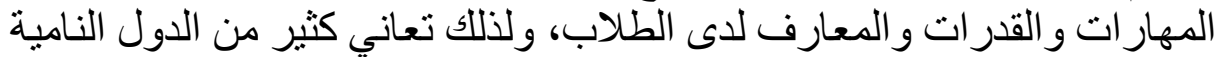

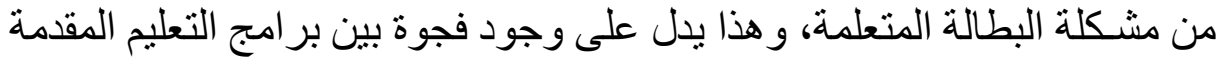

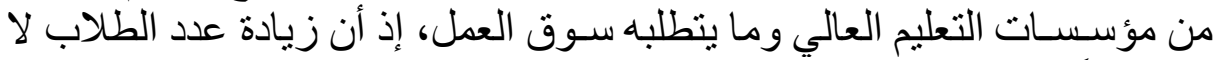

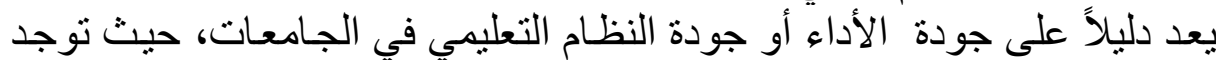
جو انب أخرى ير اعى أخذها في الاعتبار ، والتي أنثـار إليها (

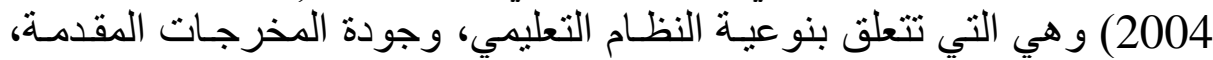

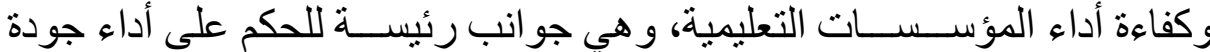

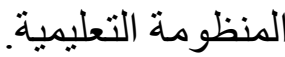

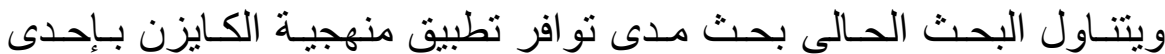

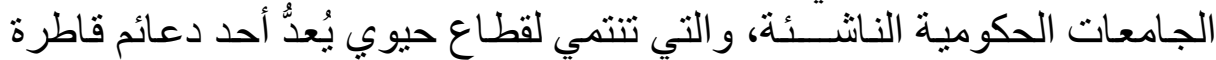

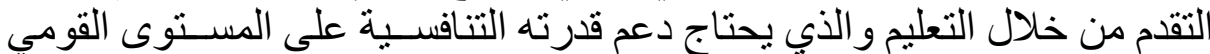

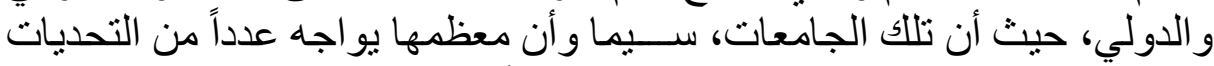

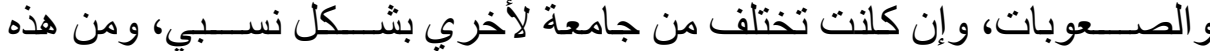

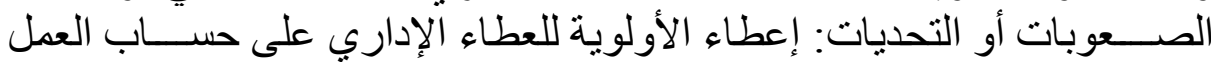

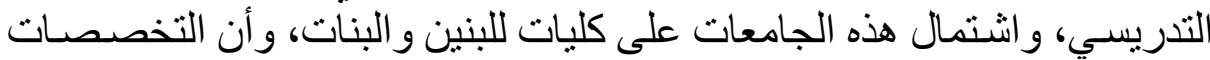

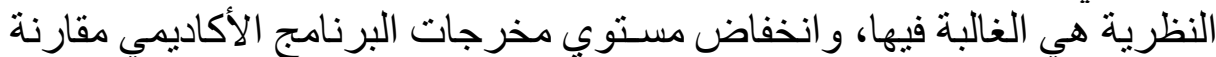

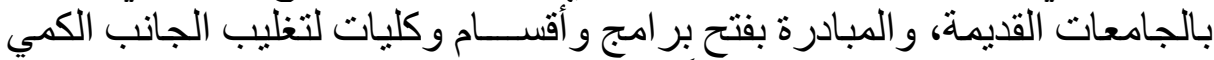

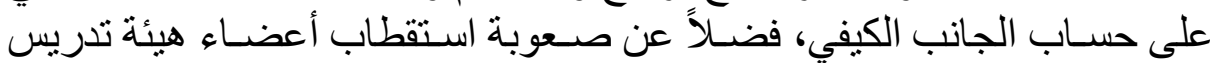

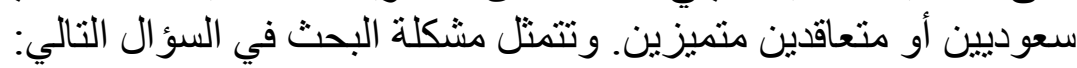

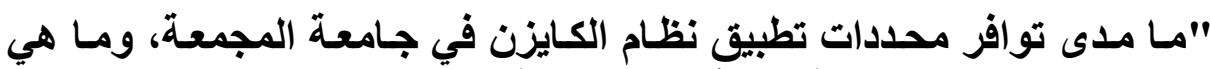

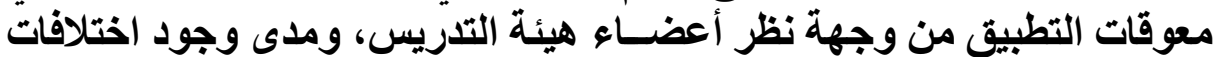
جوهرية بينها وفقا لخصائص الأعضاء؟ أعضاء هينة

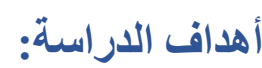

تسعى الدراسة الحالية لتحقيق الأهداف التالي:

1- إلقاء الضــو عاء على منهجية الكايزن و المفاهيم المرتبطة بها لرفع مسـتوى

الادر الك بشأنها.

2- بيان فرص تطبيق الكايزن في الجامعة من وجهة نظر أعضــــاء هيئة

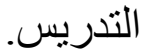
3- تحديد أهم معوقات تطبيق الكايزن في التعليم الجامعي.

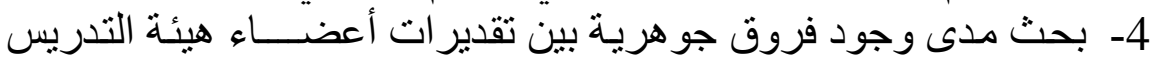

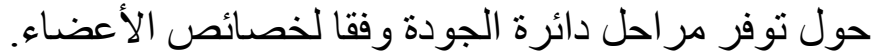
5- تقديم مجمو عة من المقترحات التطبيقية لتفعيل منهجية الكايزن بالجامعة. 


$$
\text { فروض الأراسة: }
$$

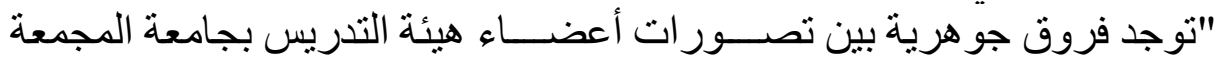

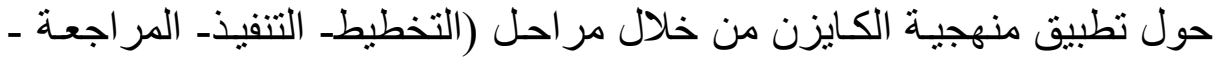

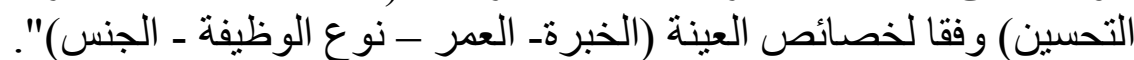

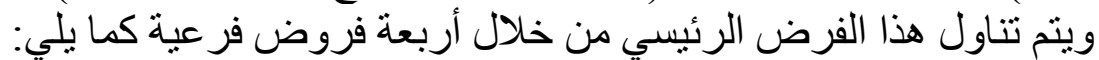

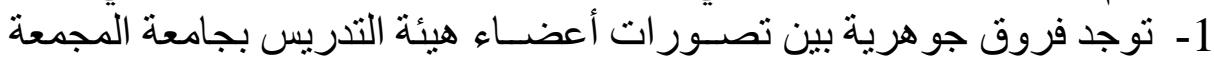

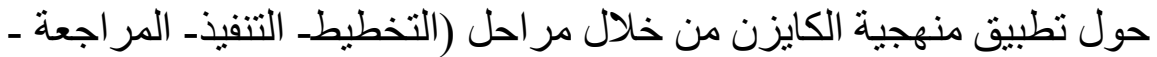
التحسين) وفقا لخبر ات أعضاء هيئة التدريس.

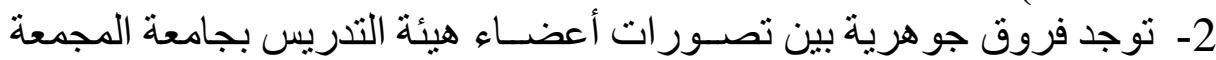

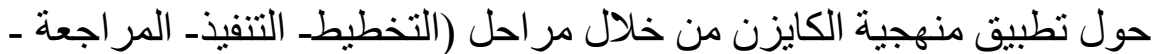
التحسين) وفقا لأعمار أعضاء هيئة التدريس.

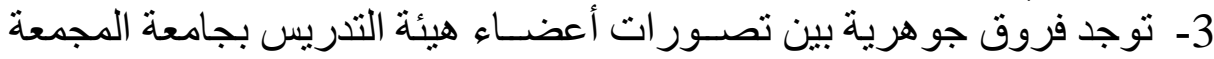

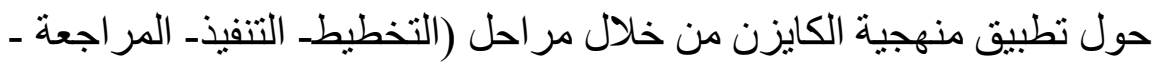
التحسين) وفقا لجنس أعضاء هيئة التدريس.

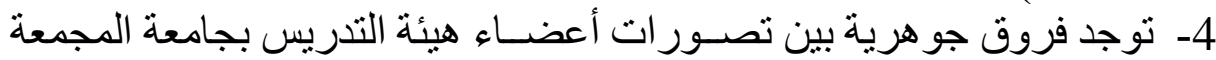

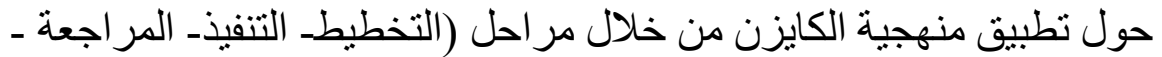
التحسين) وفقا لنوع وظيفة أعضاء هيئة التدريس.

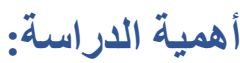
يمكن بيان أهمية الدراسة على المستويين العلمي و التطبيقي كما يلي:

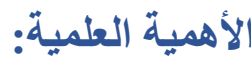

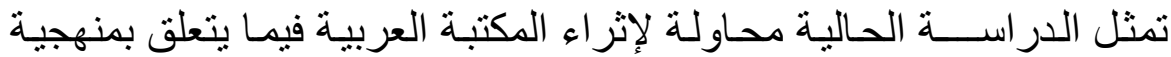
الكايزن و التي تم استيفاؤها في الغالب من المر اجع و الدر اسـات الأجنات التبية. كما أنها

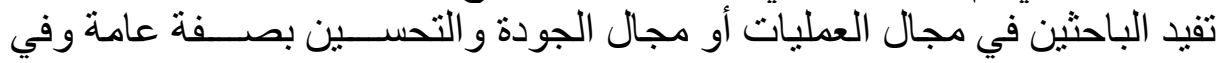
مجال التعليم الجامعي بصفة خاصة.

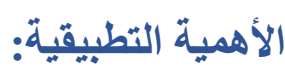

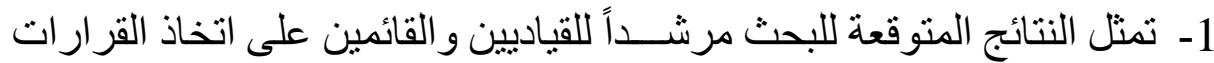

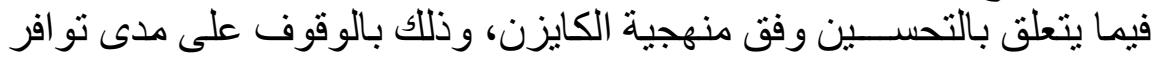
فرص تطبيقها ومعوقات التطبيق ومن ثم ينسنى لهم التخاذ التحاذ القرار ات ات المناسبة

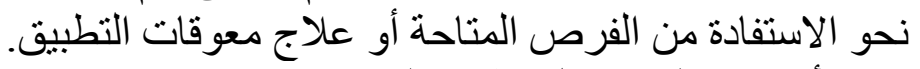

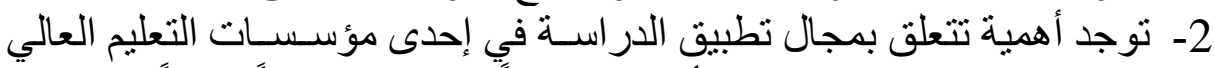

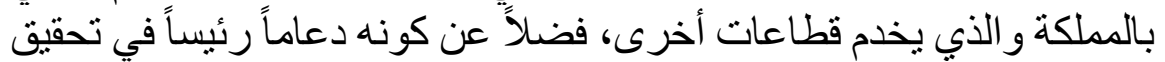

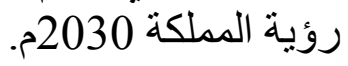

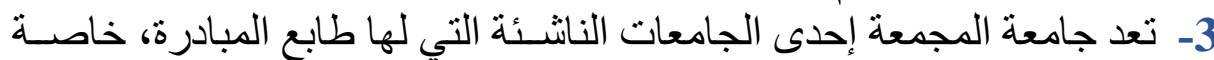

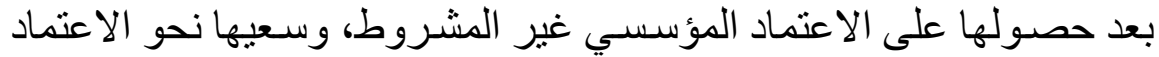
البر امجي وفي إطار خطة زمنية مدتها ثلاث سنوات الات تنتهي مع العام الجامعي 


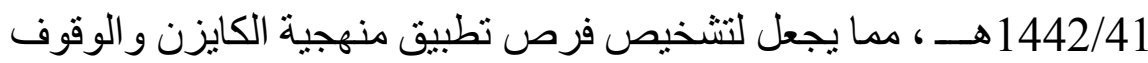
على معوقات التطبيق أهمية خاصة في تلك المرحلة.

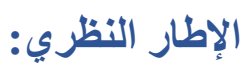
استر اتيجية دورة ديمينج.

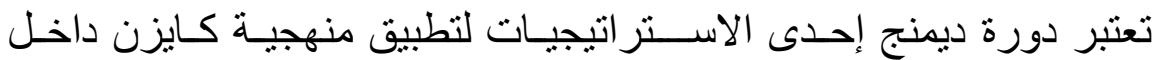

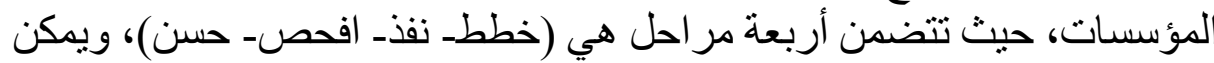
بيان هذه الخطوات الأربع في هذه الدورة كما يلي:

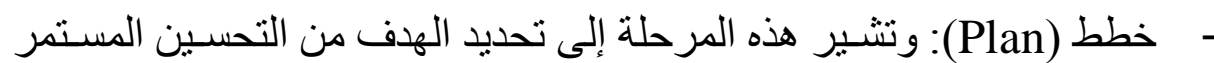

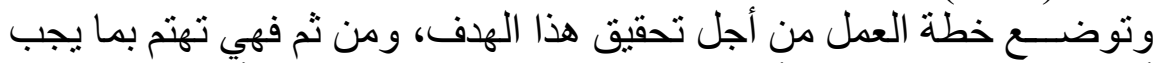

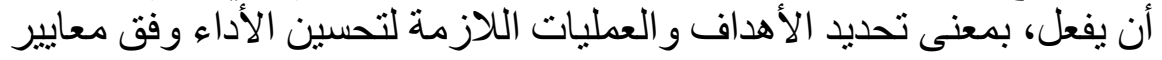
ومواصفات كفيلة بتحقيق الرضاو الاشباع. - تفذ (Do): و هذه المرحلة يتم تتفيذ ما سبق تخطيطه بالآليات المناسبة للخطة،

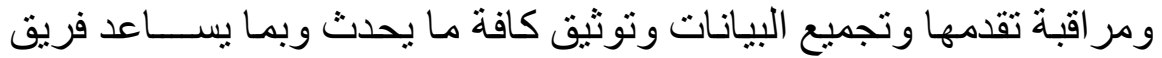

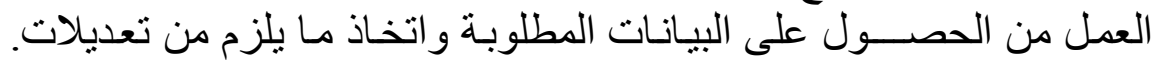

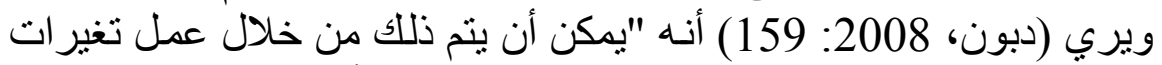

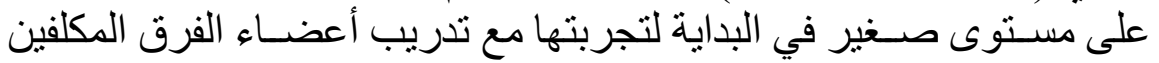

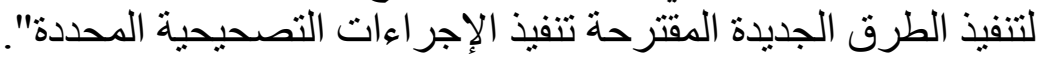

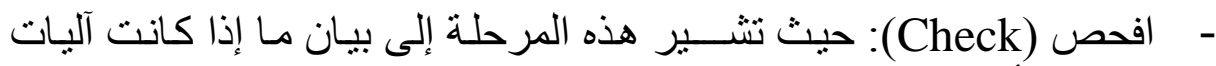

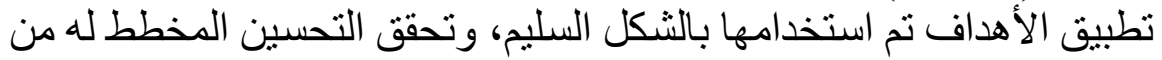

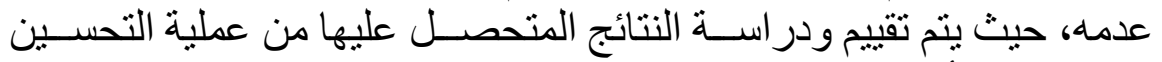
ومقار نتها بالأهداف و المو اصفات المستهدفة (Imai, 1997).

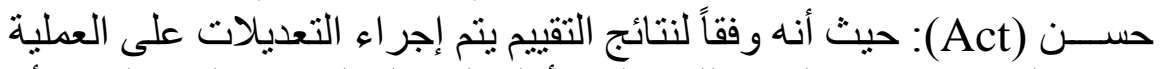

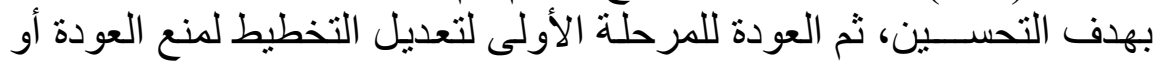
تكر ار المشكلة الأصلية ومن ثم بستمر سير الحلقة أو الدائرة (34).

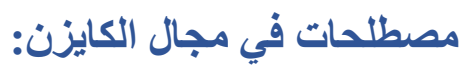

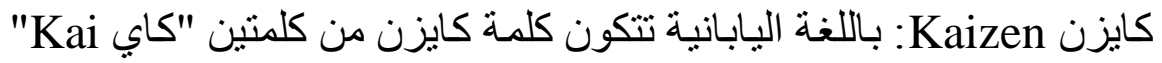

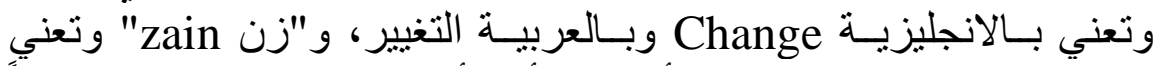

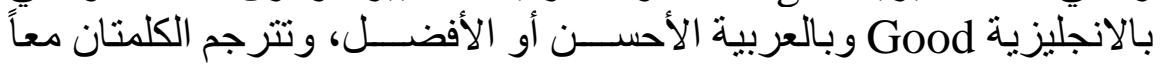

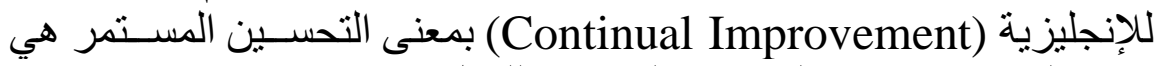

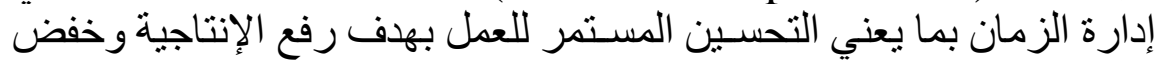
التكاليف، (Imai, 2012, 25). جيمبـا Gemba: وتعني إدارة الدكـان، بمعنى أن تكون الإدارة في موقع الأحداث و لا تنفلك عنه.

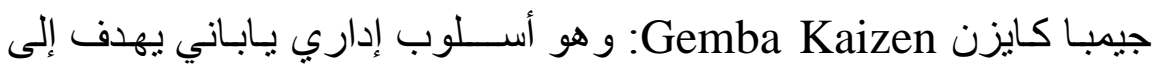

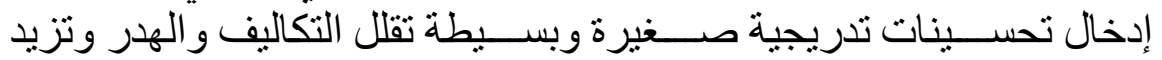


الإنتـاجيـة، ويمكن ترجمـة معنى الكلمتين في "الإدارة من موقع الأحـداث"

.(Imai, 2012, 11)

نظرية جيمبا كايزن Gemba Kaizen Theory: نتجبت هذه النظرية من

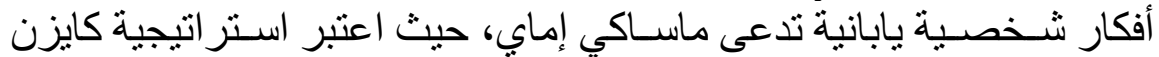

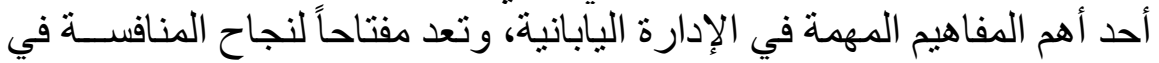

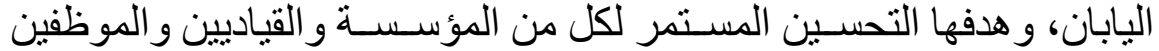

.(Dysko, 2012)

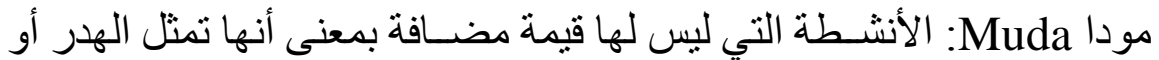

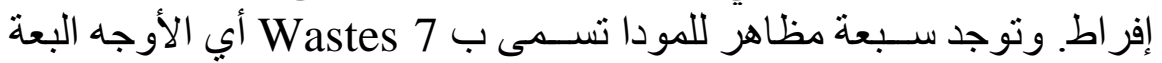

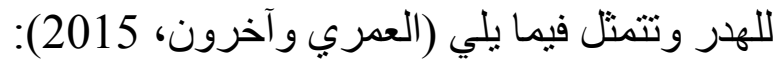

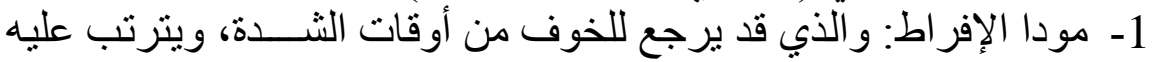
تكس في المو اد و الإنتاج.

2- مودا التخزين: من خلال وجود كميـات من المعدات و الأثــــــاء التي لا تنتمي للنشاط.

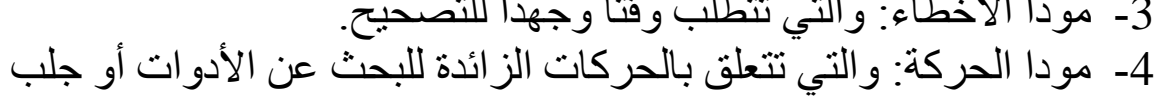

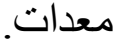
5- مودا التدفق: و التي تتنج من عدم انسيابية العمليات بين الأقسام.

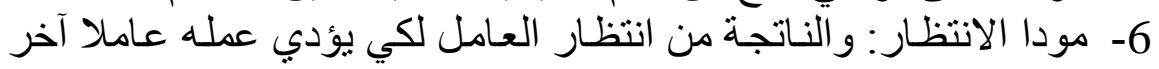

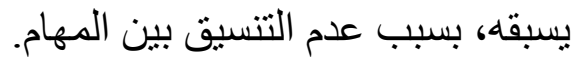
7- مودا النقل: و التي تنتج من عمليات النقل بلا طائل. • • موري Muri وتعني تخفيض إجهاد الفرد و الآلة. مورا Mura وتعني التقليل من الاختلاف و التغيرية، وتخفيض عدم التافية التناغم و الاتساق و الثبات في النظام

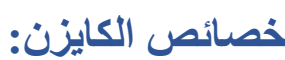
تعتبر الكايزن عملية تحسين دائم وتتميز تتميز بما يلي:

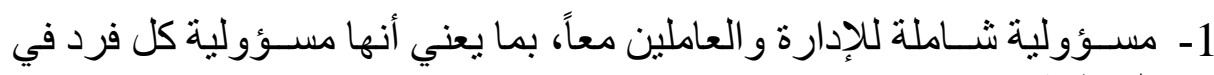
المنظمة. 2- و هي توليفة متكاملة من الفكر الإداري ونظم العمل، و أدوات تحليل المشكلات

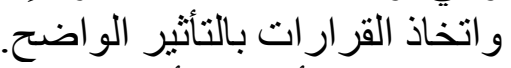
3- تركز على الأماكن الأهم استراتيجياً. 4- 3- تحقق نتائج سريعة. 5- تحافظ على استمر اريتها و على التغيير و التحسين التدريجي، حيث أنها تتكون

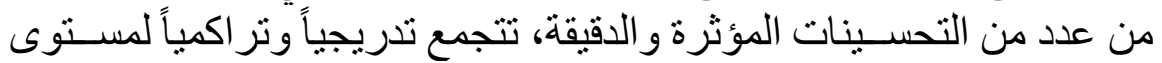
الأداء وبدون انقطاع، ودون تحمل تكاليف كبيرة. 
الإدارة التقليدية والإدارة بأسلوب كايزن:

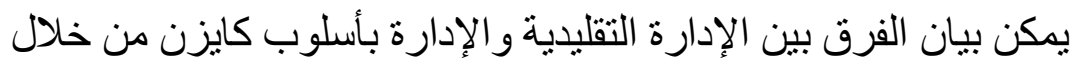

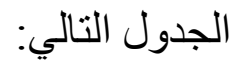

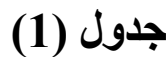

\begin{tabular}{|c|c|}
\hline الإدارة بأسلوب كايزن & الإدارة التقليدية \\
\hline العمليات هي المشكلة & الموظفون هم المشكلة \\
\hline يتعاون الجميع لإنجاز العمل & كل شخص يقوم بعمله \\
\hline كل شـخص اءو يعرف كيف يتناسـب عمله مع & كل شخص يفهم بعمله \\
\hline التزركيز على قياس الأداء بشكل عام & الأفركيز على قيـاس أداء \\
\hline العمل على تغيير العمليات & العمل على تغيير الأشخاص \\
\hline الععل على تقليل الأخطاء & العمل عل تصحيح الأخطاء \\
\hline الا هتمام بمن سمح بحدوث الخطاً & الا هتمام بمن ارتكب الخطاً \\
\hline
\end{tabular}

*Joshi, A., (2013), Implementation of Kaizen as a continuous improvement tool: A Case study, International Journal of Management Research and IT, ISSN- 2320-0065. تمنح استر اتيجية كايزن الموظف صداحية التغيير في مجال عمله بينما تقصر

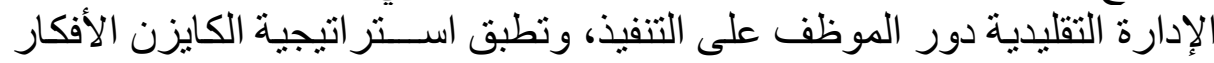

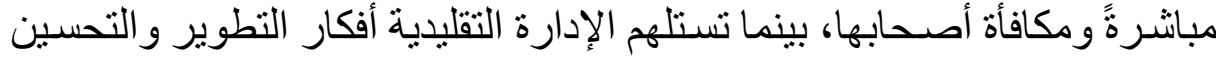

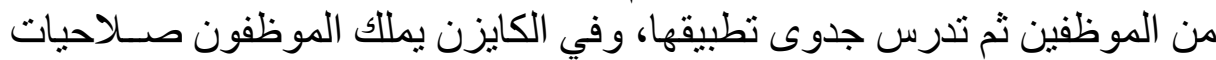
عديدة في عمهم اليومي بينما تقصر الإدارة التقليدية الابداع على الإدارة العليا.

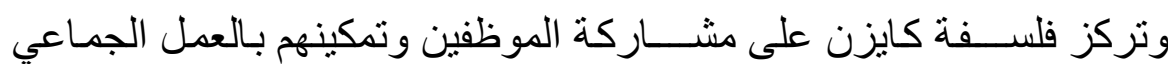

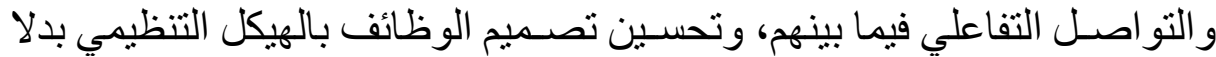

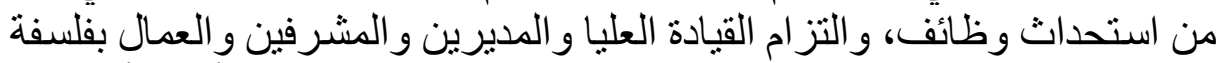

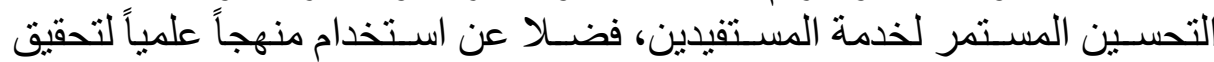
العيب الصفري (Thessaloniki, 2006). إجراءات تطبيق الكايزن: حتى يمكن تحقيق أهداف الكايزن بفاعلية توجد مجموعة من الإجر اءات يتم

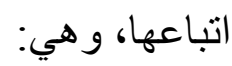
1- التبني و الدعم للمنهجية من جانب الإدارة العليا.

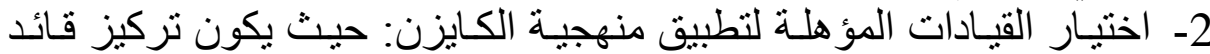

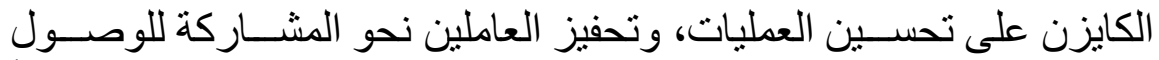

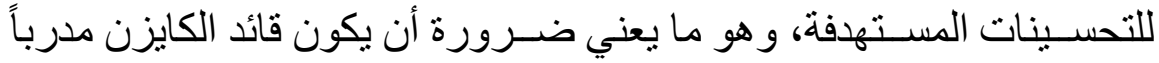


على مهار ات الالتز ام و اسـتثـار الوقت وتحفيز المرؤوسـين وتتمية مهار اتهم و التو اصل مع الآخرين ومشناركتهم (Joshi, 2013).

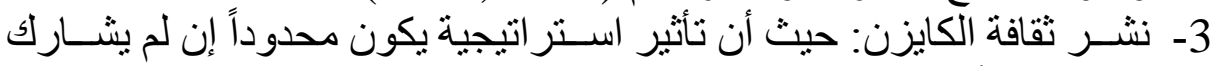
الجميع في أنشطتها.

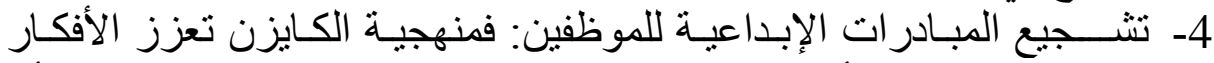

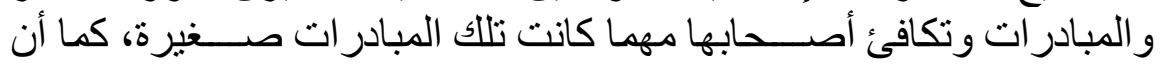
المبادر ات تدعم التز ام الموظفين بقيم وثثافة المافئ المنظمة.

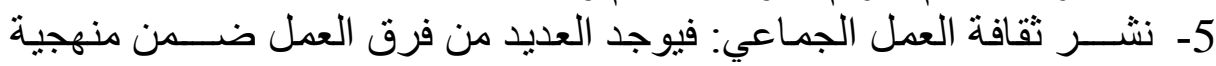

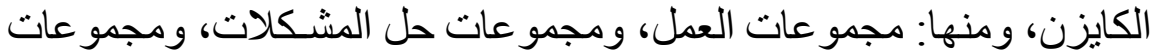

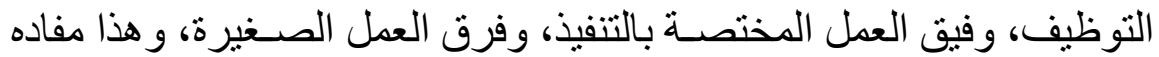

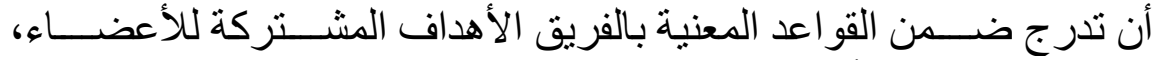

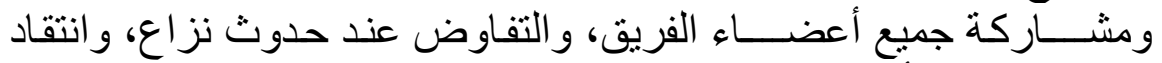
العمليات دون الأفر اد (Imai, 2012).

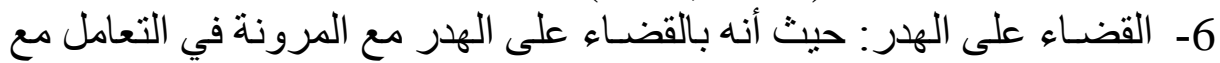

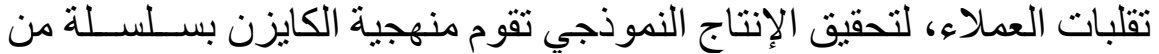

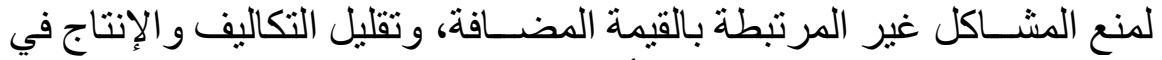
الوقت لمناسب مما بساعد في دعم أرباح المنظمة (Imai. 2012).

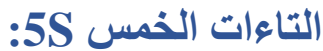
تستخدم التاءات الخمس 5S في كثير من الدر اسات جنباً الى جنب مع الكايزن،

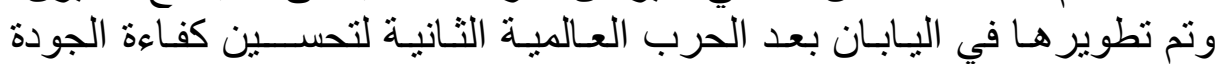
(Becker, 2001)، حيث تستند إلى خمس مصطلحات يابانية لنقل مبادئ التدبير

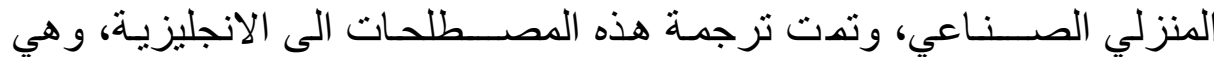
(Chapman, 2005) ; (Becker, 2001) ; (Avari et al. 2011) ; (Randhawa and Ahuja, 2017); (Warwood and Knowles,

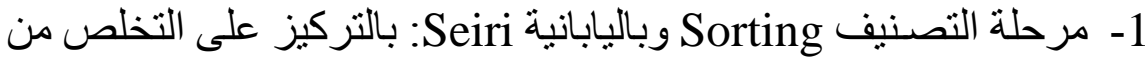

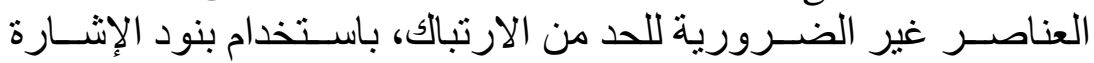

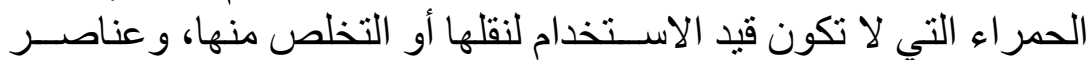

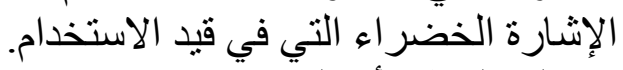

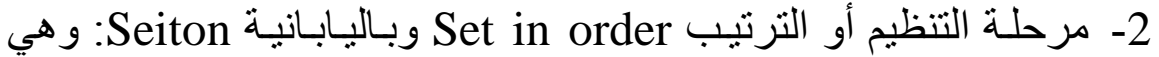

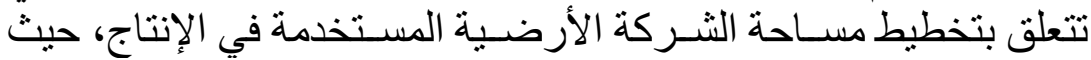

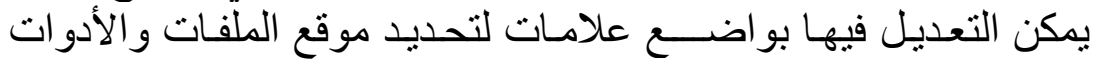

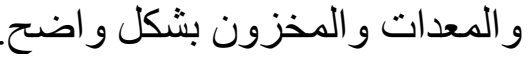

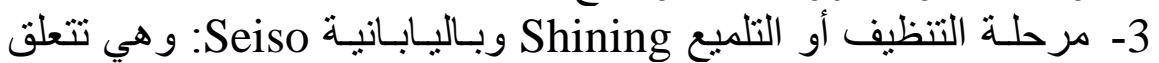
بتنظيف أرضية الإنتاج وتوفير المعلومات لتنظيف الآلات. 
4- مرحلة التنميط Standardize وباليابانية Seiketsu: من خلال إنثــــاء

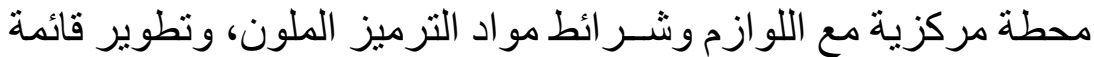

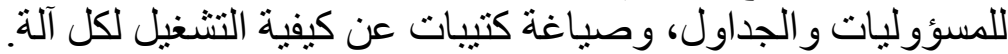

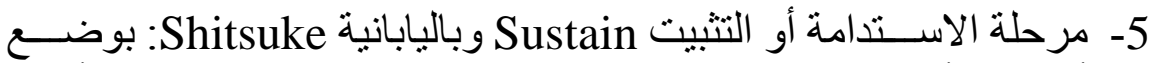
أنظمة للتأكد من إدارة القو اعد الجديدة، حتى يتسنى إدارة 5S من الألهية الإنية

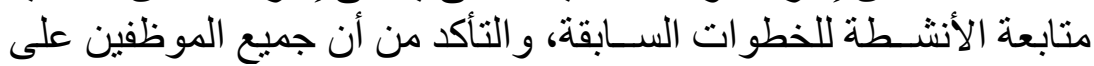

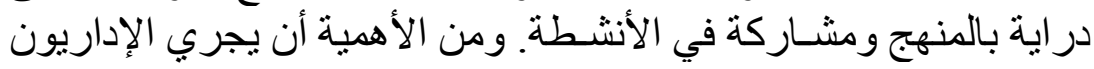
عمليات تدقيق منتظمة لمبادئ

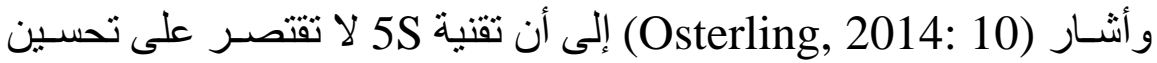
البيئة المادية للعمل، بل تحسن إدارة الجودة الكلية للعمليات.

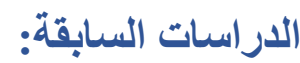

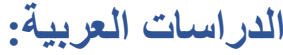

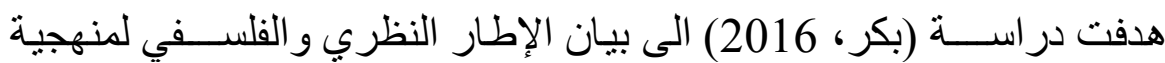

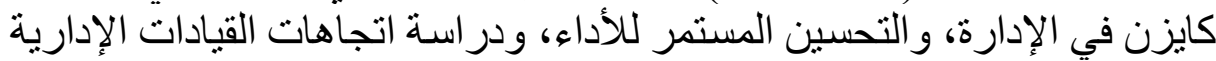

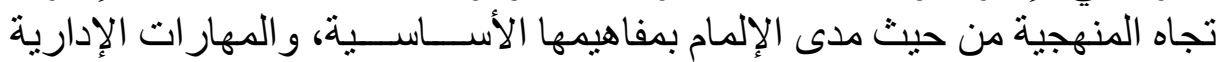

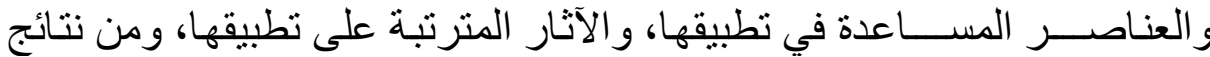

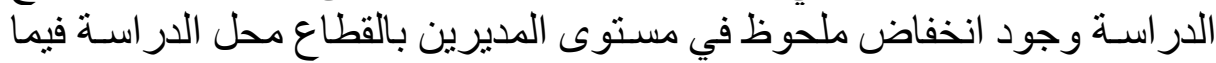

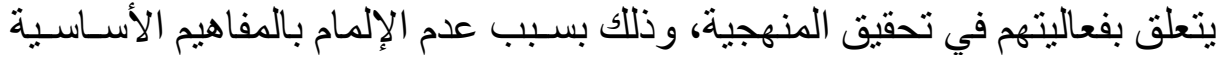

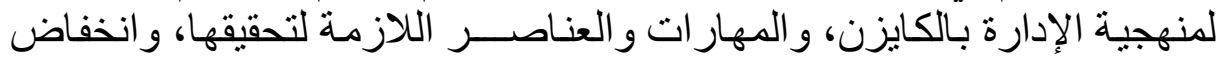

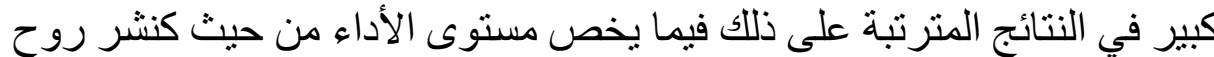

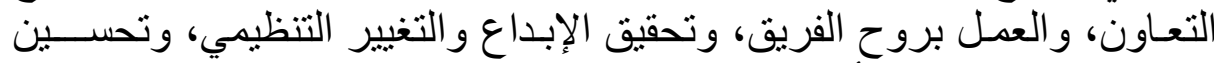
جودة الخدمة وسر عة الأداء، ورضا العربه العملاء به.

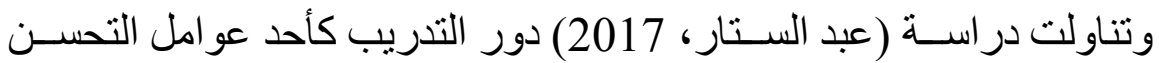

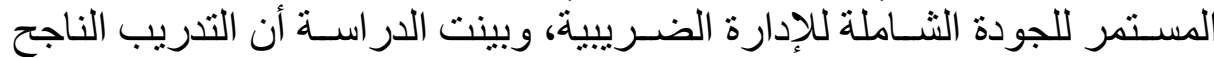

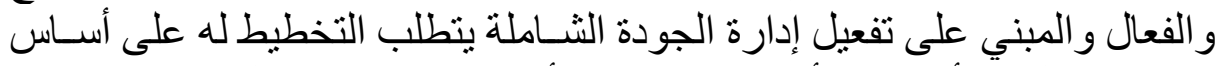

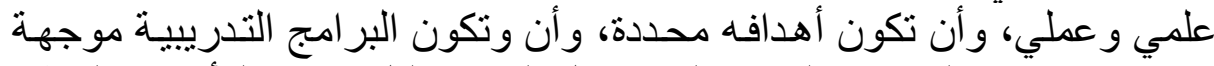

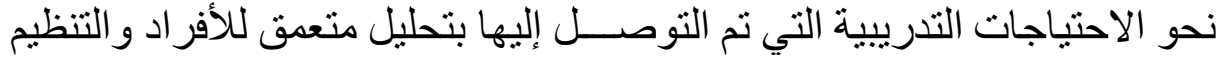

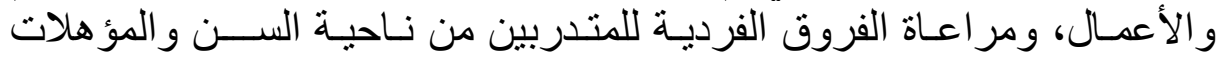

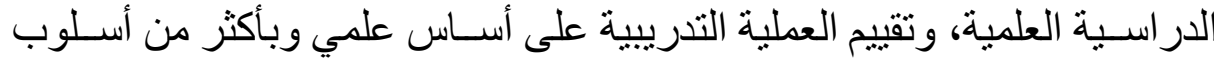

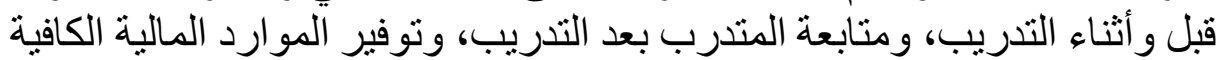

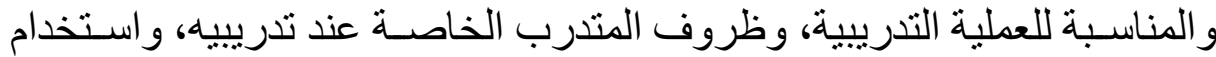

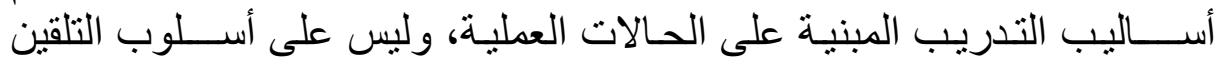

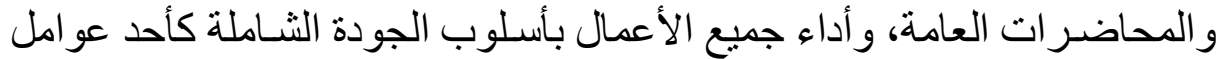

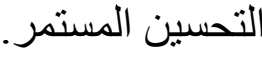

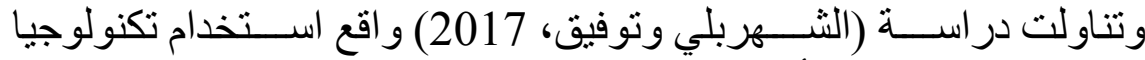

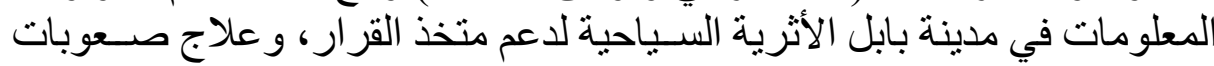


عديدة تواجه العاملين في تكنولوجيا المعلومات، وتقادم قو اعد البيانات العاملة،

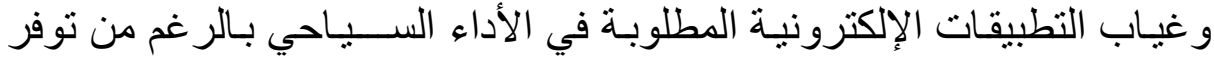

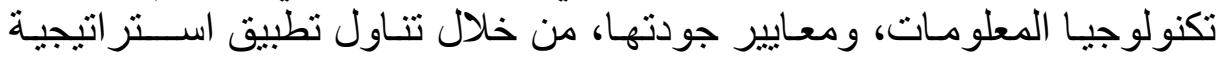

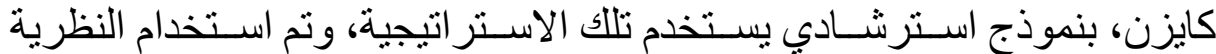

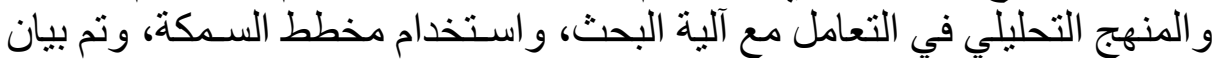
مجمو عة من الحلول و البدائل الافتر اضية للتحسين.

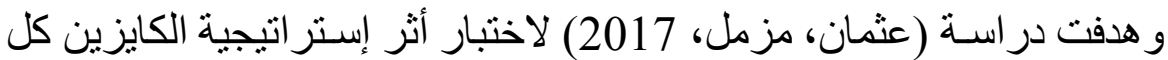

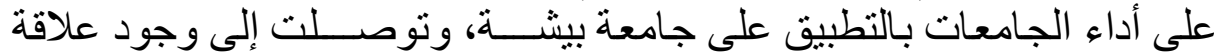

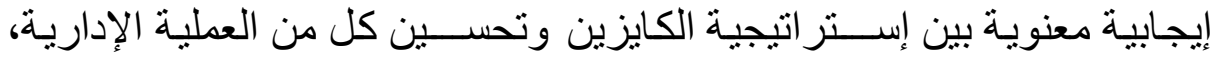
و العملية التعليمية، و الخدمات المجتمعية للجامعة.

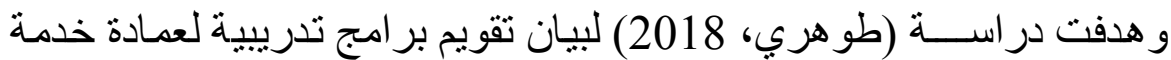

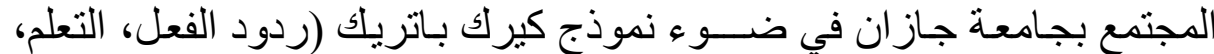

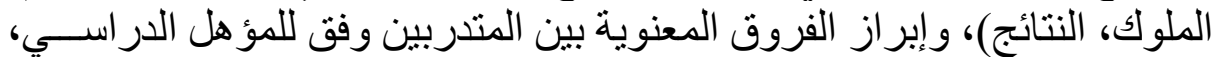

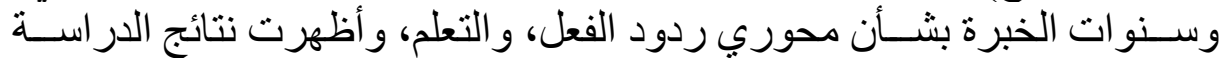

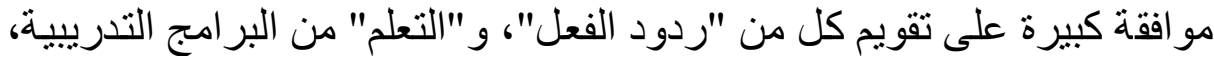

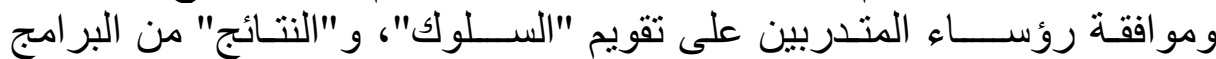

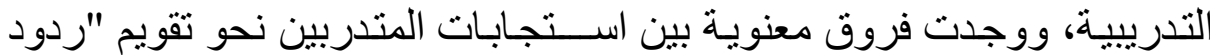

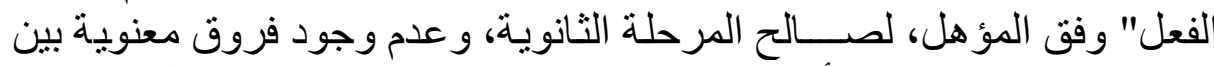

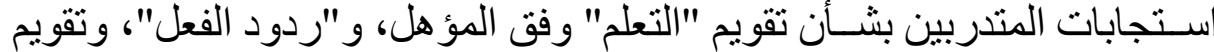

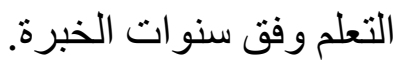

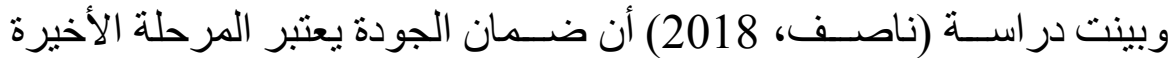

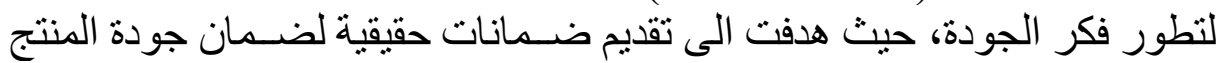

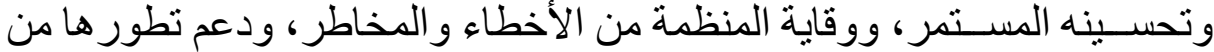

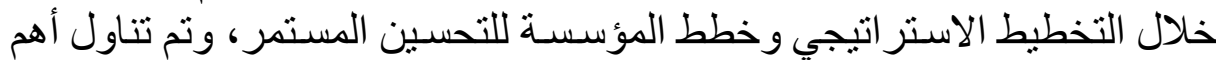

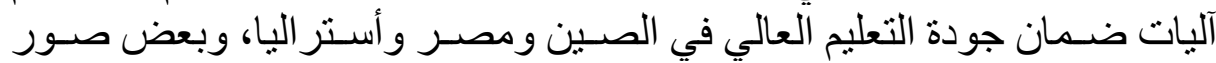

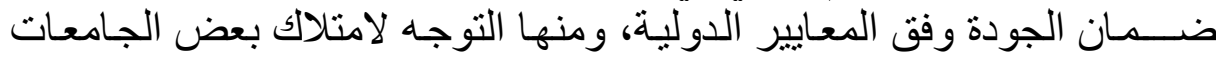

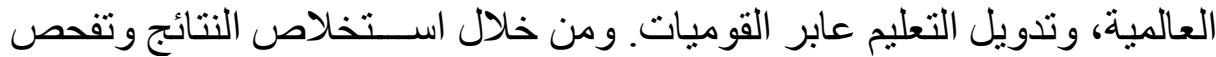

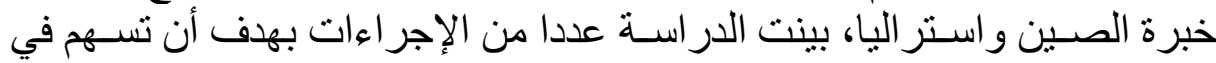
تفعيل ضمان جودة بالمؤسسات المصرية الرانية

و هدفت دراسة (الطائي، 2018) لمعرفة أثر أنشطة سلسلة القيمة على التحسين

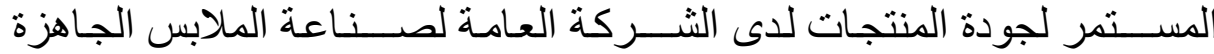

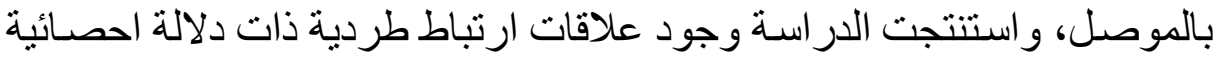

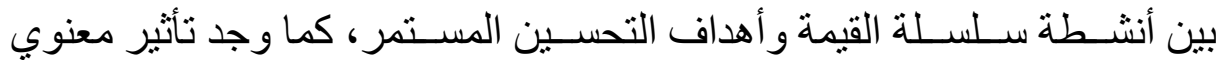
لأنشطة سلسلة القيمة في أهداف التحسين المستمر لجودة المنتجات. 


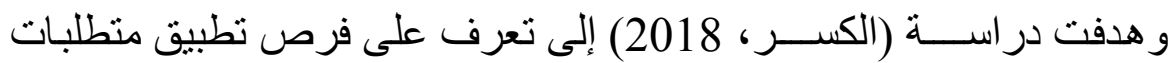

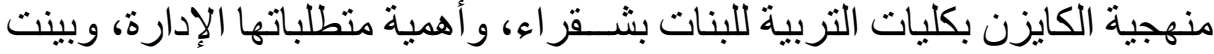

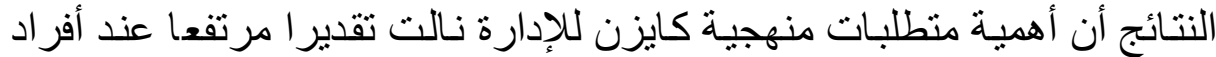

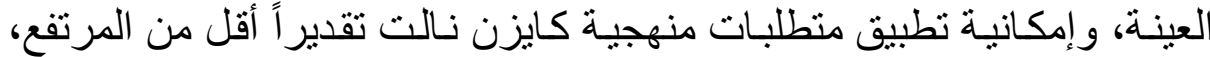

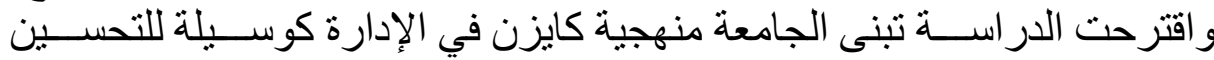

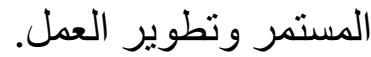

و هدفت دراســة (الوحيدي، 2018) إلى التعرف على إدارة الجودة الثــــاملة

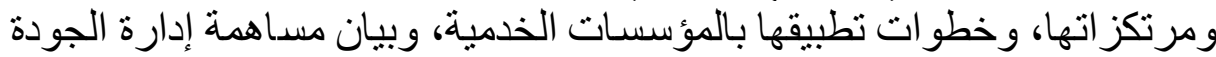

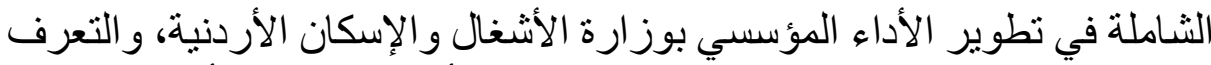

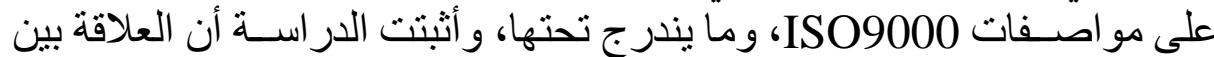

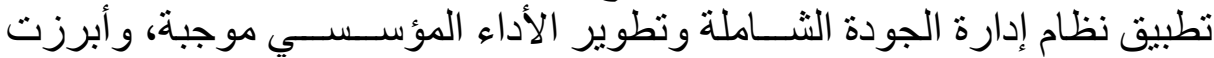
الدر اسة أههية تطبيق إدارة الجودة الثشاملة في وز ارة الأشغال و الإسكان الأردنية

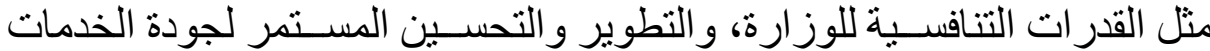

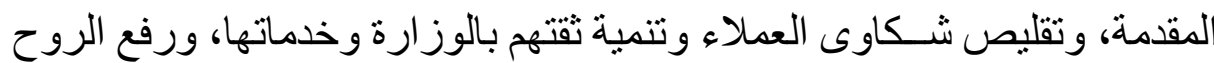

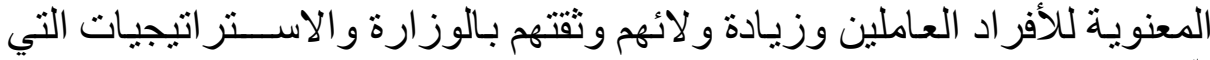

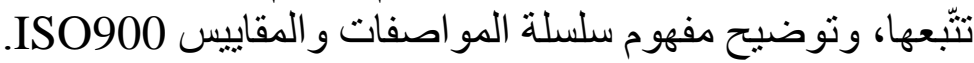

وتتناولت دراســـة (التمي ومرعي، 2018) التطور ات الحديثة لقياس الأداء

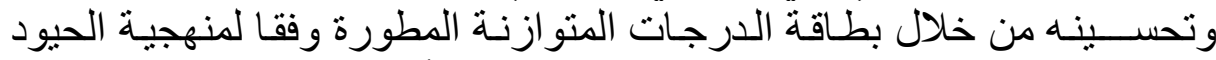

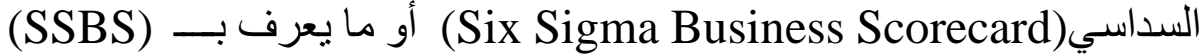

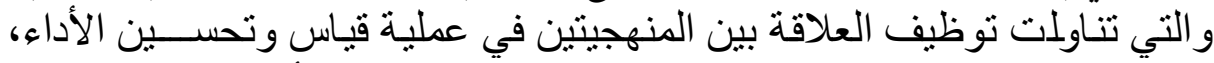

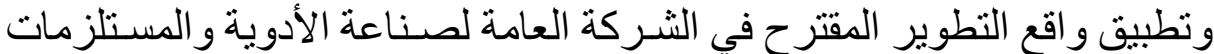

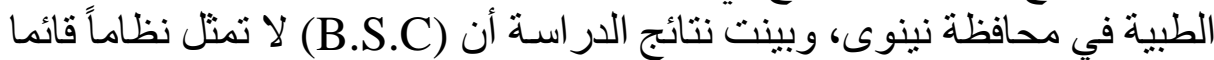

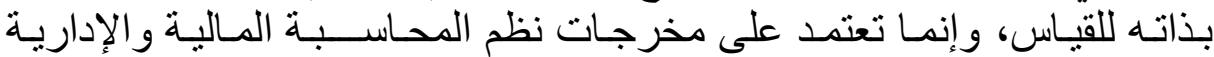

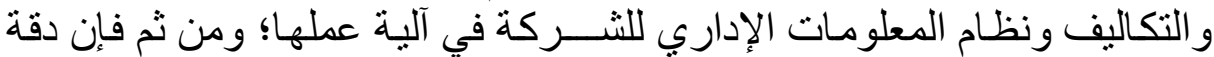

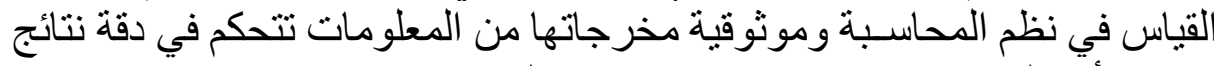
قياس الأداء لـ (B.S.C) ونجاحها في تحقيق التحسين.

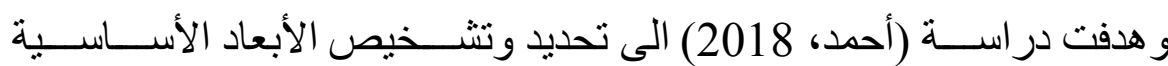

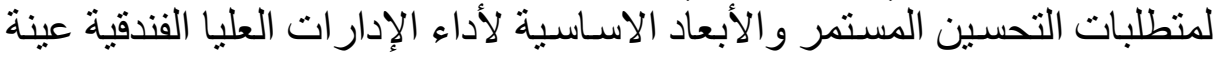

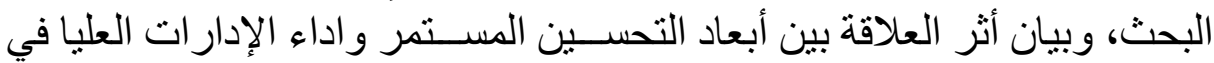

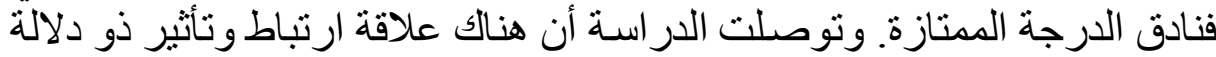

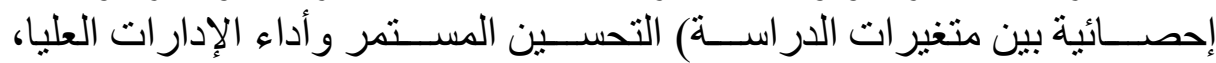

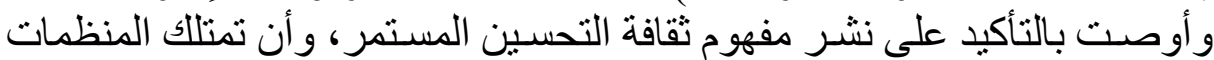

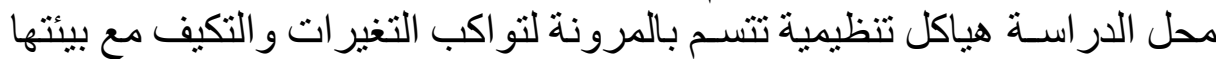

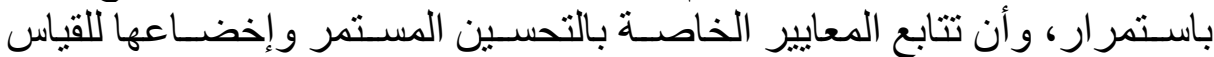

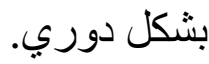


و هدفت در اسة (الحو امدة و الثرمان، 2018) إلى التعرف على إمكانية تطبيق

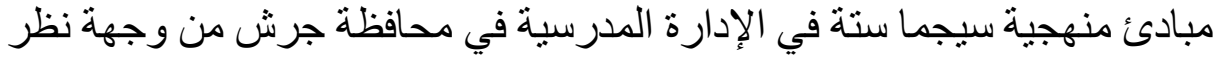

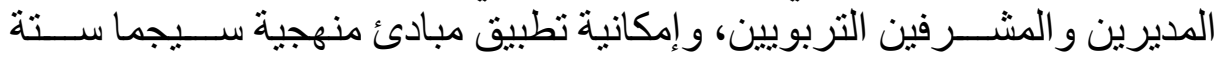

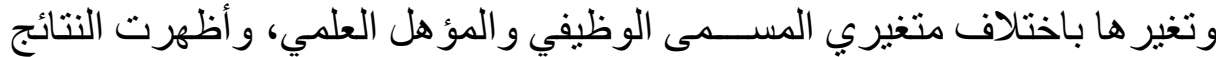

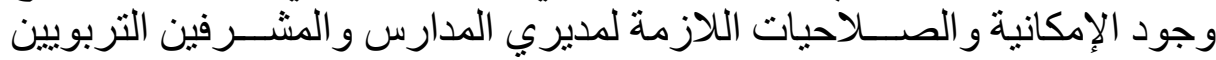

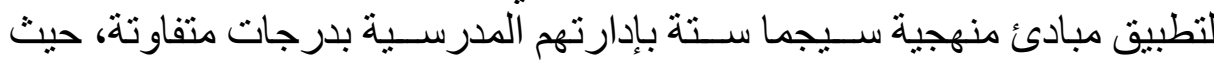

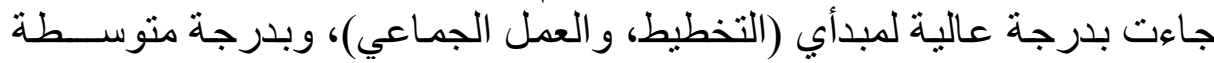

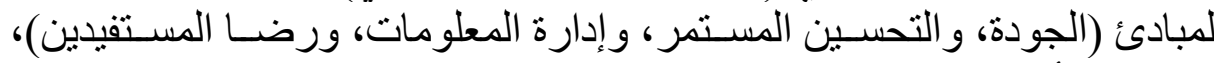

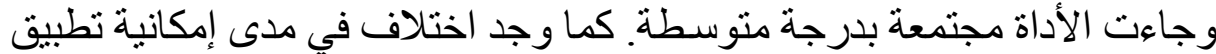

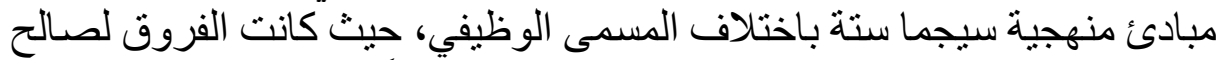
المديرين، و لا يوجد فروق في مدى إمكانية التطبيق تبعاً لمتغير المؤهل العلمي.

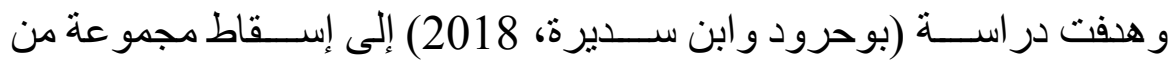

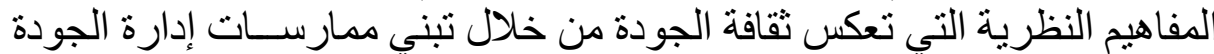

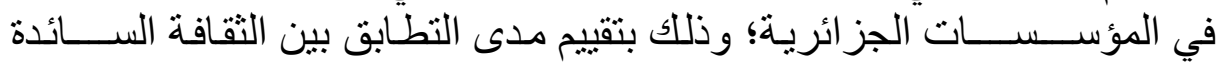

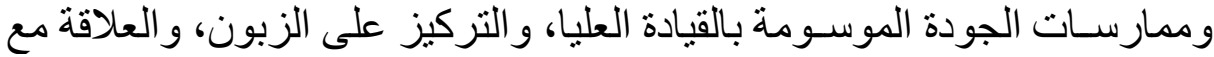

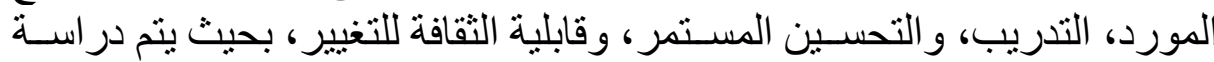

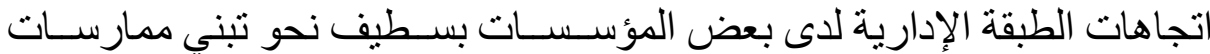

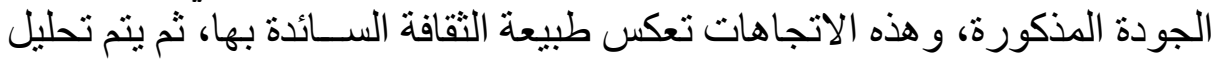
معوقات التحول نحو ثقافة الجودة في المؤسسات محل الدر اسة.

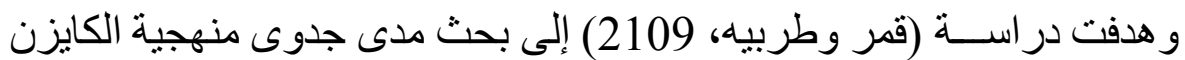

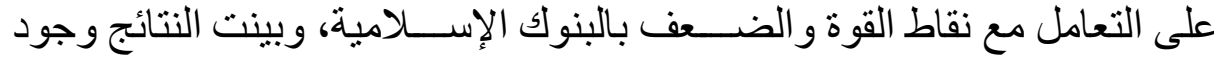

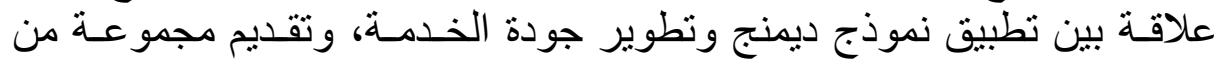

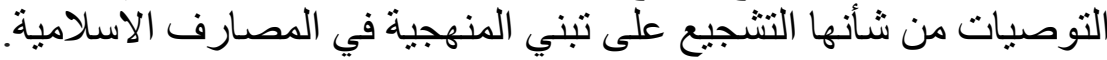

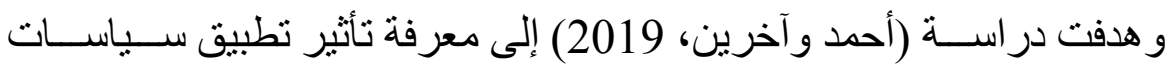

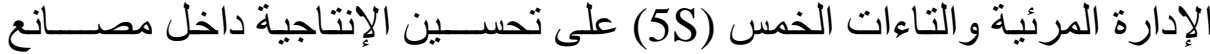

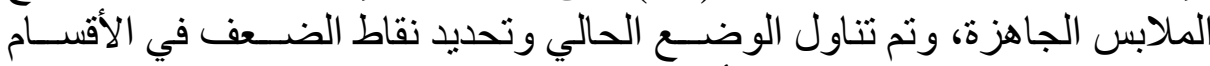

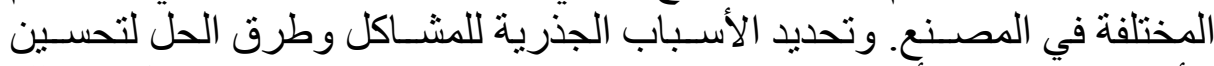

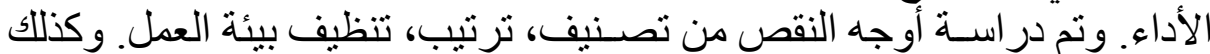

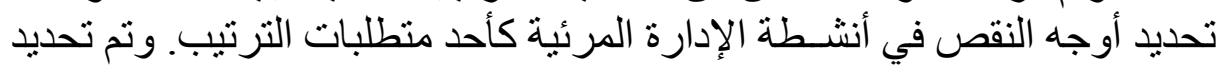

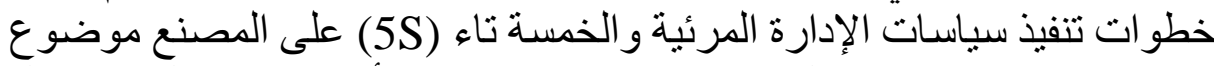

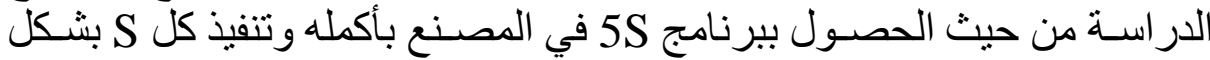

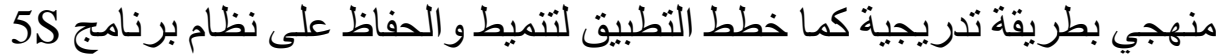

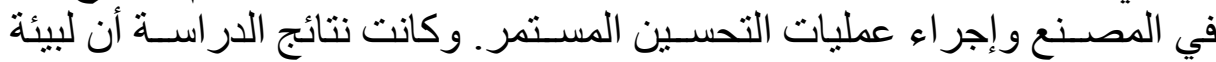

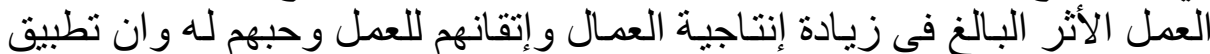

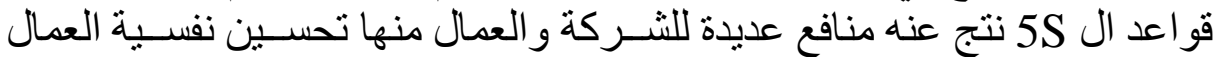

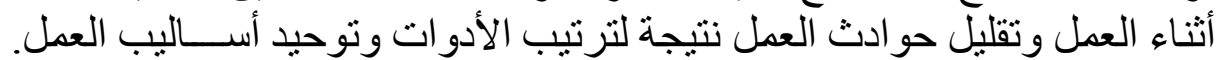


وكذلك تقليل الجهد و الوقت المبذول للقيام بالعمل، وبالتالي رفع إنتاجية العمال

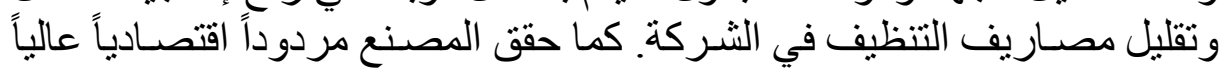
بسبب تطبيق تلك القو اعد.

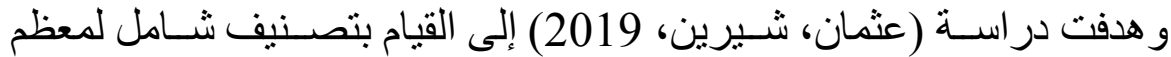

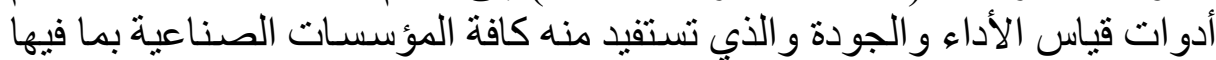

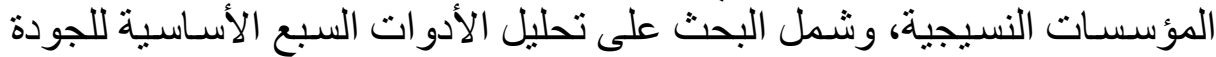

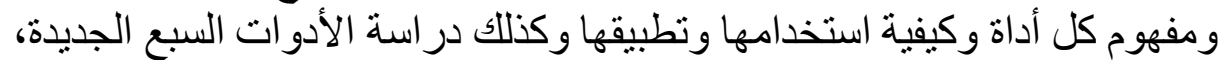

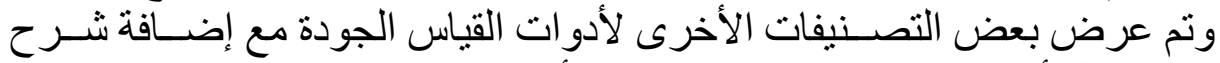

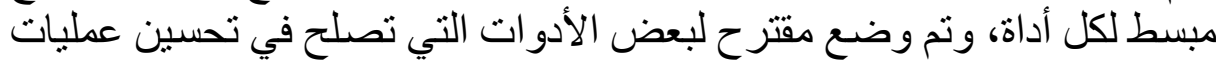
نظم الجودة للمؤسسات النسجية و هذا يمثل مقترح بحثي من الادر الباحث.

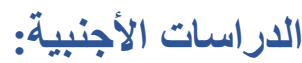
هدفت در اســـة (keeley, 2004) إلى تحديد مدى فاعلية ممارسئسـة إدارة

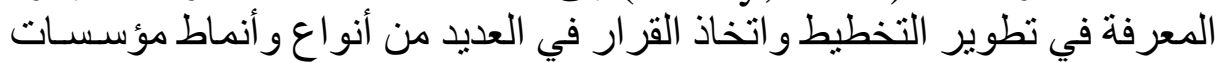

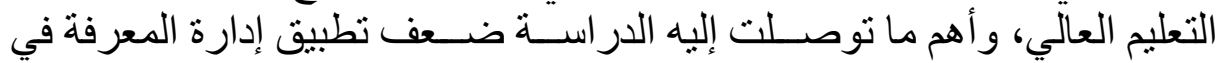
تحسين التخطيط وصناعة القرار في مؤسسات التعليم العالي وأن أفضل التئل الأساليب

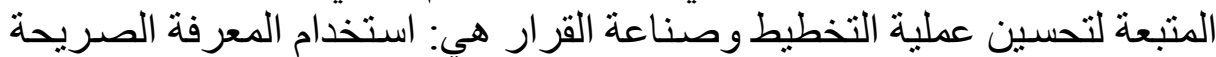

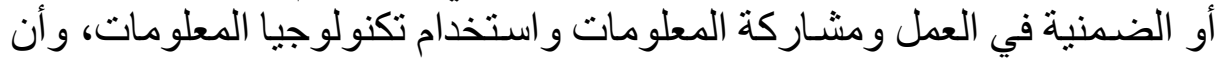

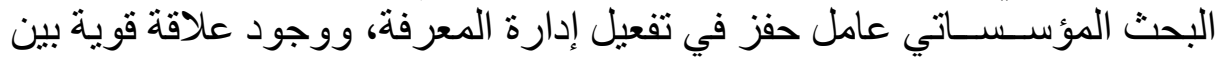

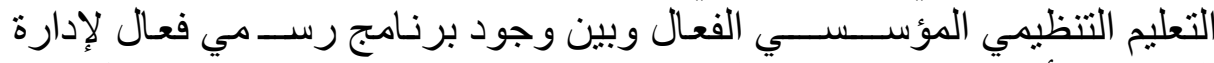

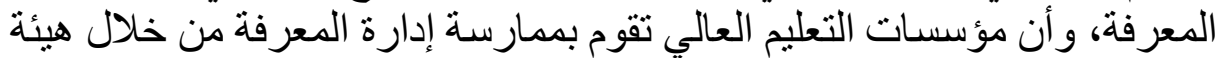

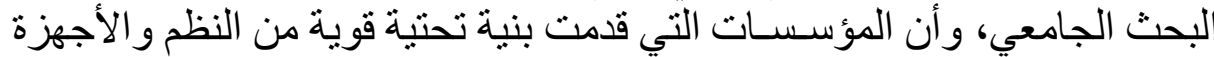

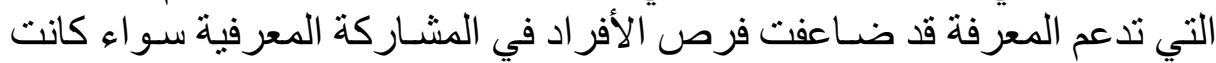

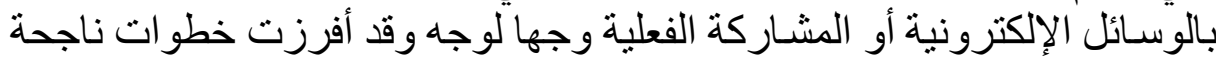

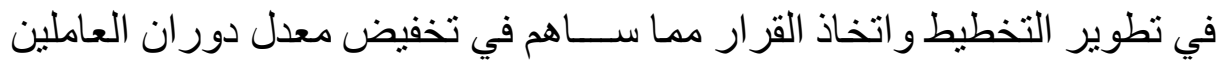

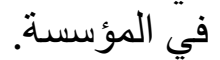

و هدفت دراسـة (Thalner, 2005) إلى تحديد العو امل التي تعوق التحسين

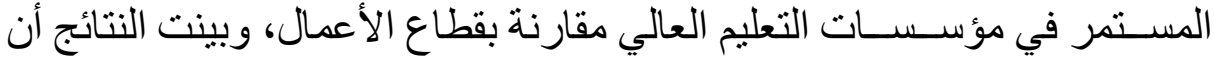

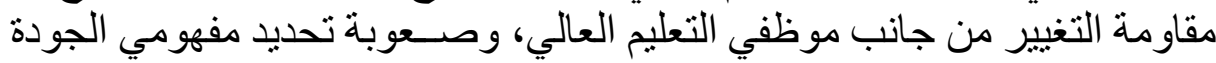

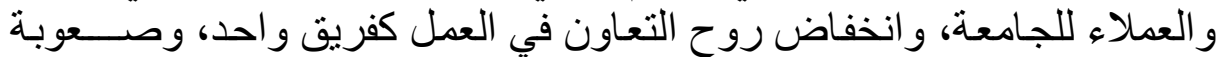

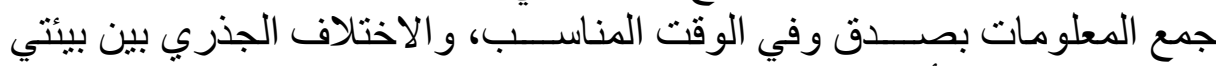
الجامعية للقطاع الأعمال و الخاص.

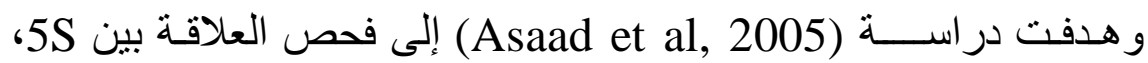

و الكايزن و الأداء التنظيمي، وكذلك فحص مسـنتوى تنفيذ

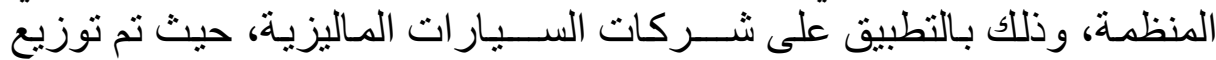

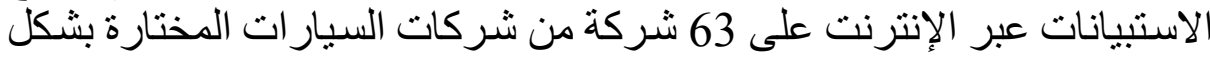

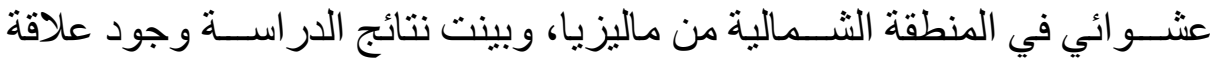




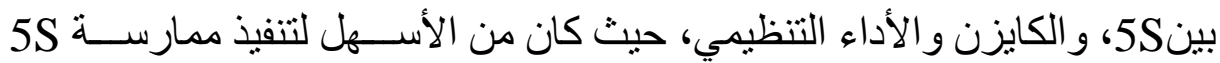

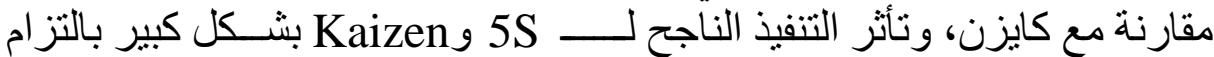

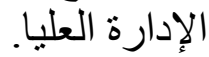

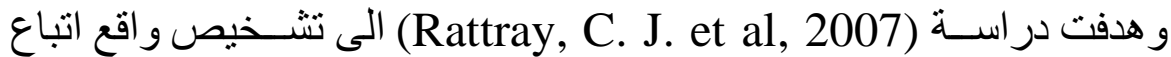

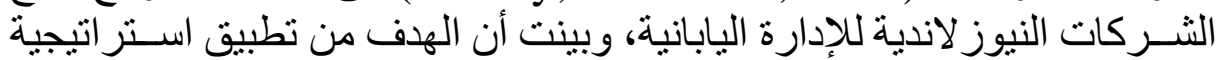

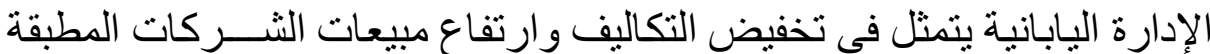

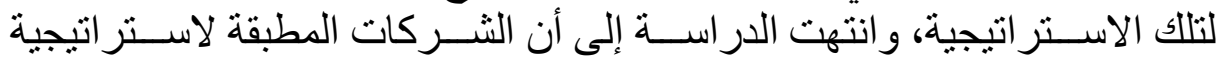
التحسين المستمر تمكنت من زيادة مبيعاتها مقارنة بالثركات النشات النظيرة.

و هدفت در اسـة (Karkoszka, \& Honorowicz, 2009) إلى تحفيز تنفيذ

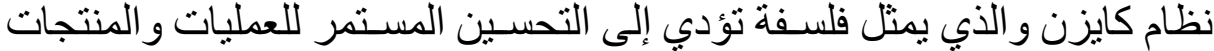

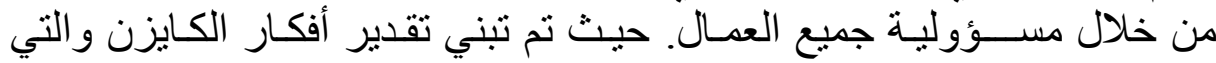

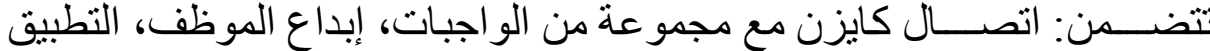

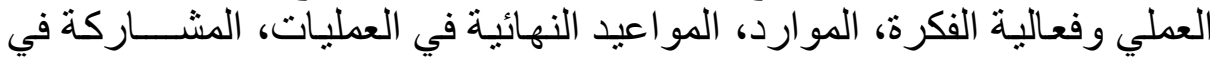

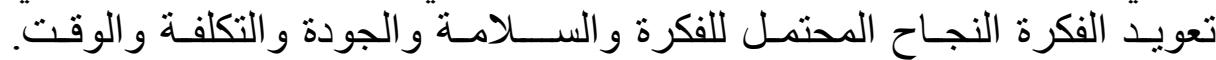

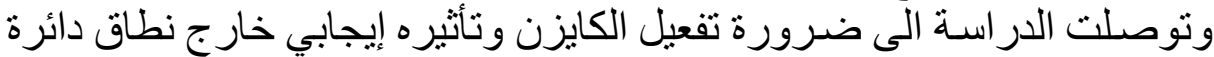

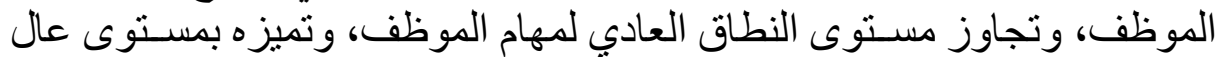

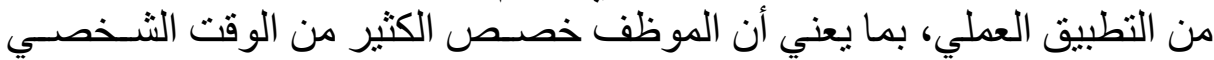

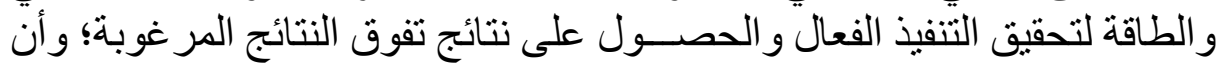
يتم التأكد من الأداء الصحيح لنظام كايزن وفق الإحصائيات العملية.

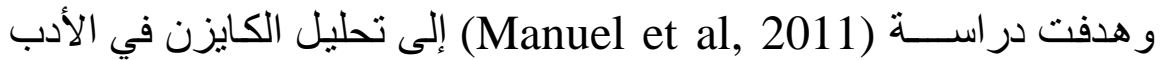

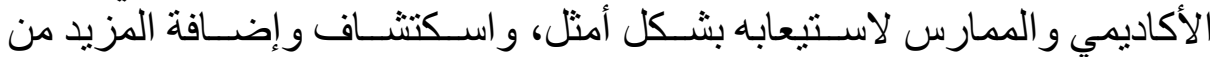

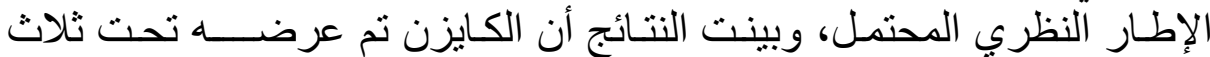
منظور ات تتعلق بالمبادئ و التقنيات، ومجمو عة من المبادئ التوجيهية.

وبينت دراســة (Gratiela Dana BOCA, 2011) أن إدارة الكايزن يتم

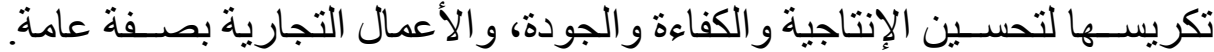

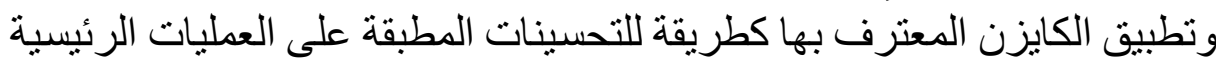

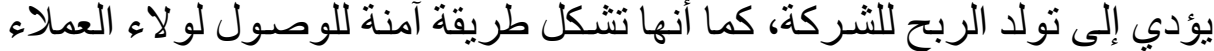

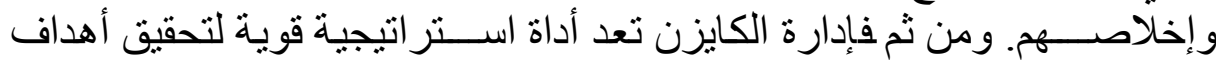

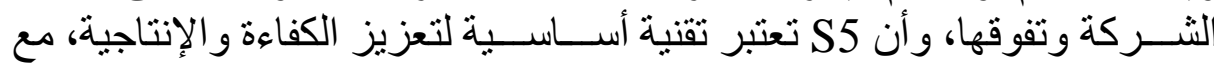

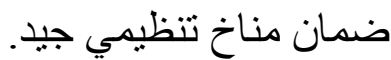

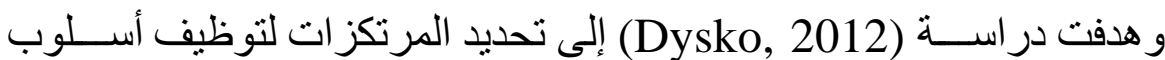

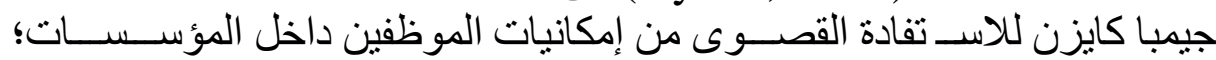

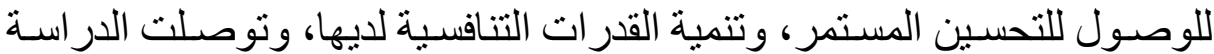

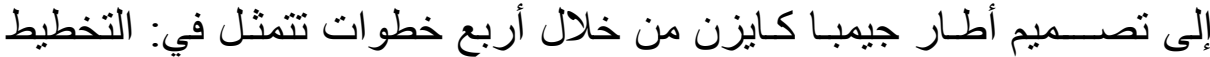
وتحديد الاجراءات اللازمة للأداء، وتو افر الإمكانات المادية و البشرية، والتنفيذ. 
و هدفت دراســة (Joshi, 2013) إلى نثـر مفاهيم فلسـفة الكايزن وتطبيقها

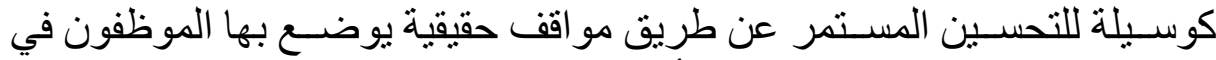

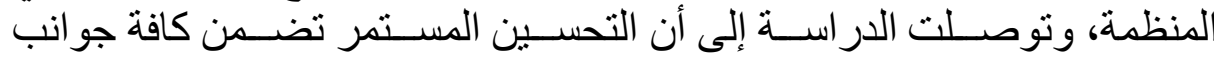

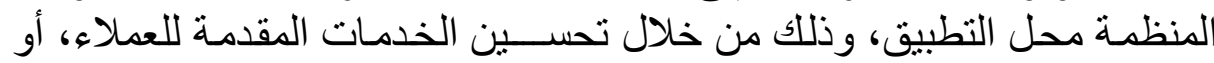

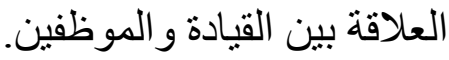

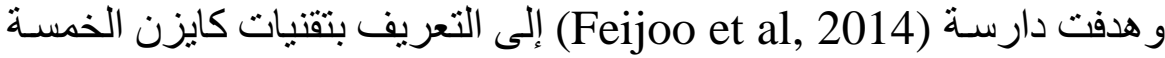

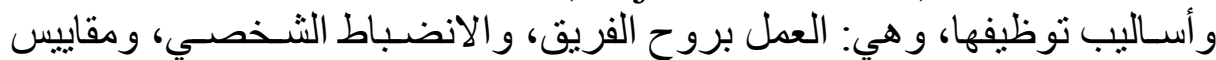

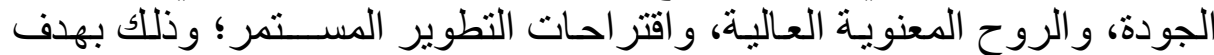

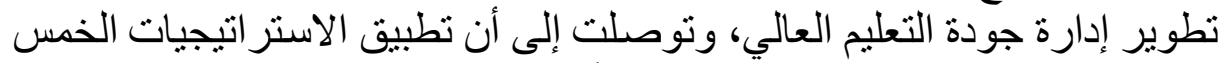

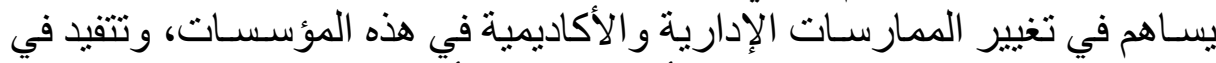

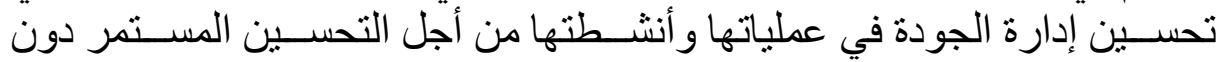

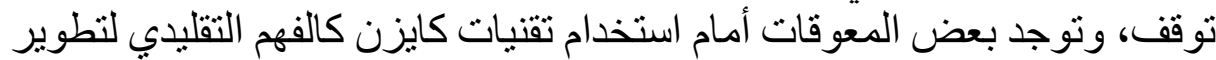

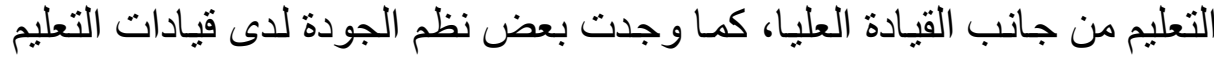

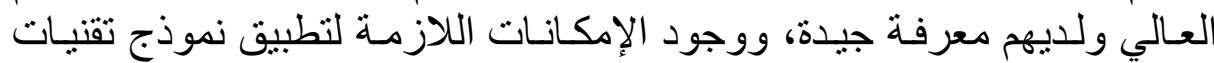

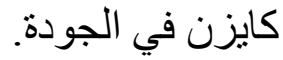

و هدفت دراســـة (Sevtap, 2015) إلى تطوير أداة لقياس فعالية كايزن

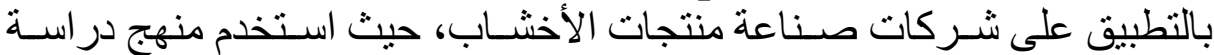

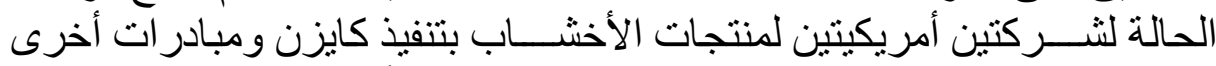

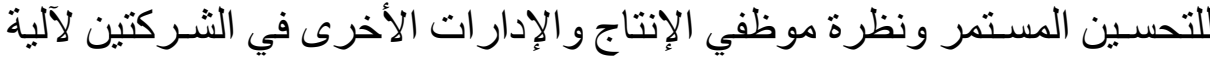

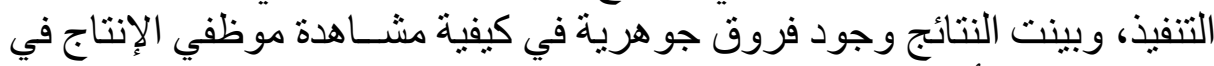

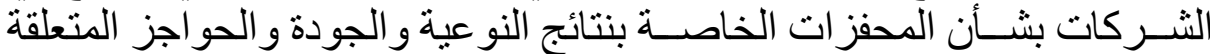

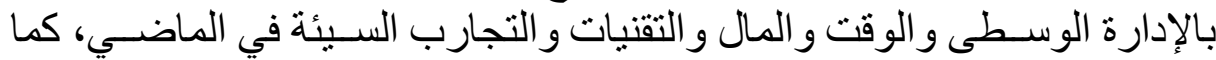

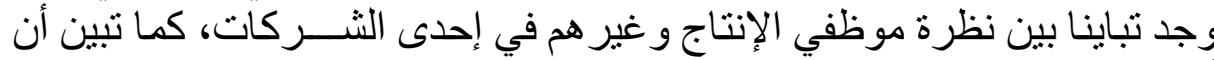
أهم مؤشر للتنبؤ بالفعالة في تنفيذ الكايزن هو إدر الك التحسينات الإنتاجية.

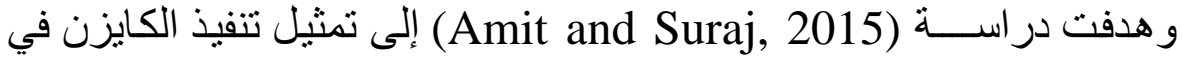

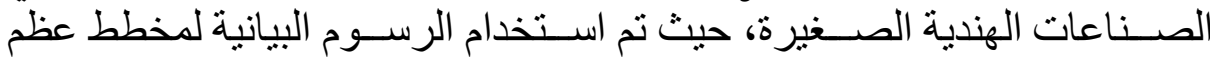

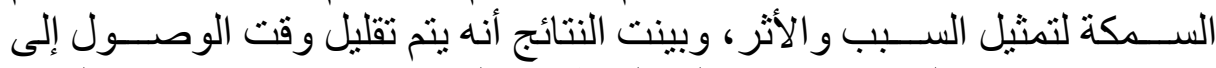

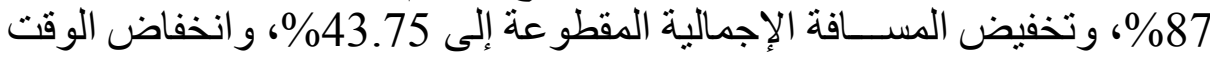

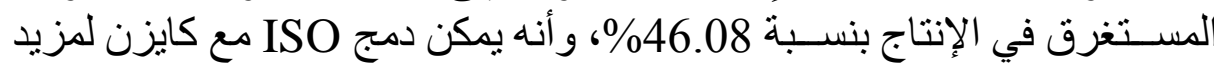

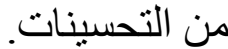

و هدفت دراســـة (liuxing et al, 2015) الى تطبيق منهجية الكايزن في الفي

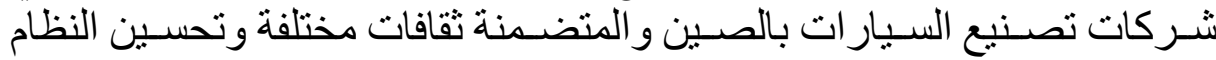

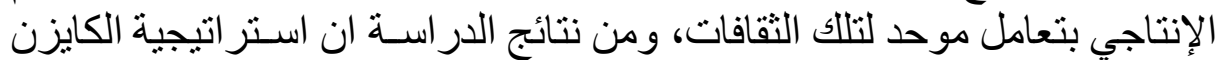

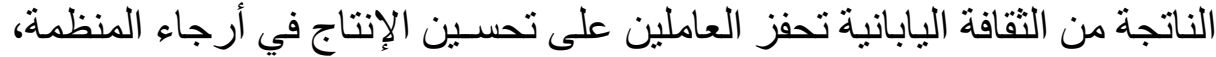

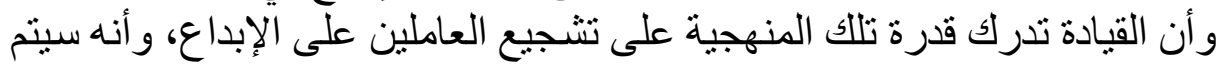
تفعيلها في التحفيز المادي مثل المعنوي. 


$$
\text { التعليق على الاراسات السابقة: - ملات }
$$

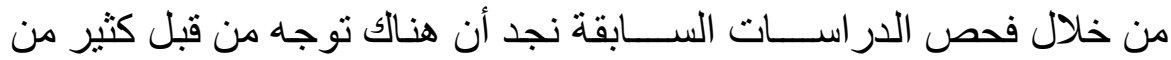

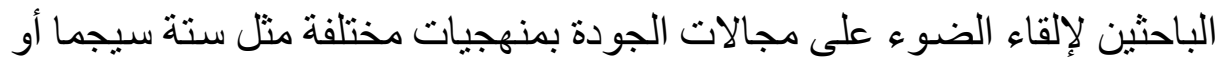

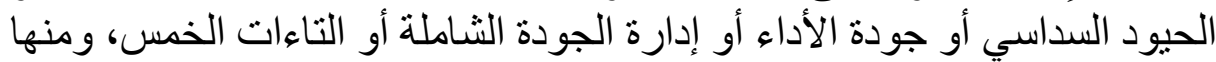

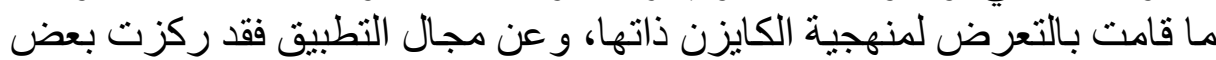

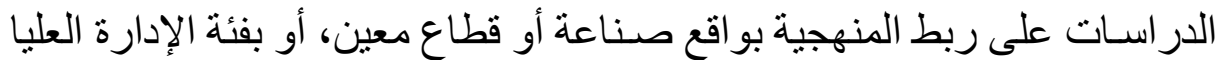

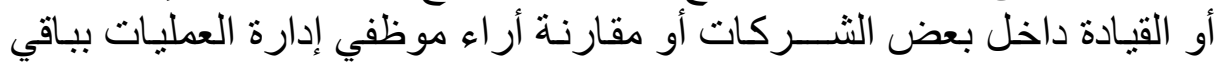

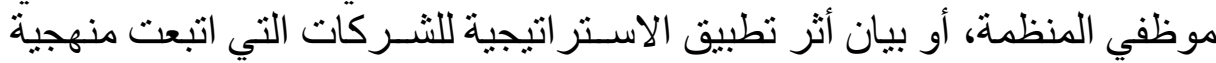

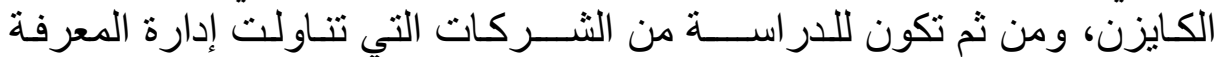

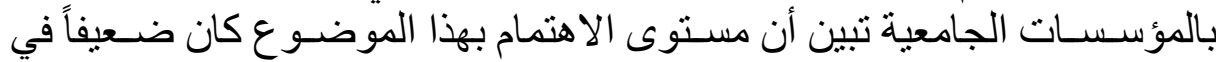

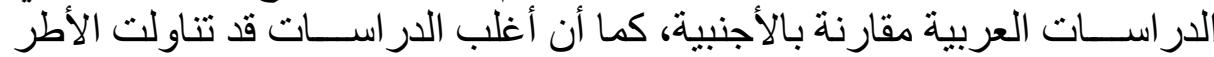
النظرية والمنطلقات الفكرية لإدارة المعرفة بالمؤسسة الجامعية.

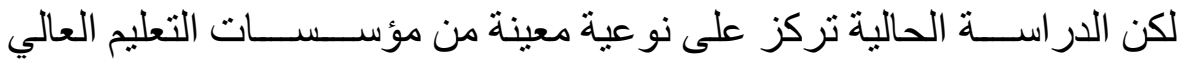

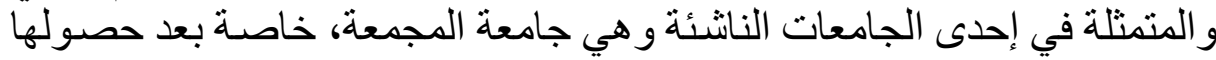

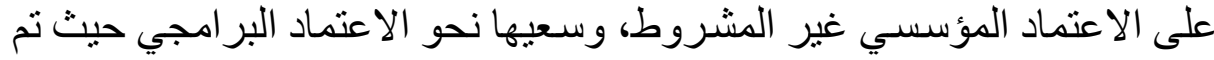

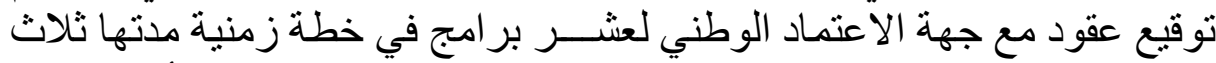

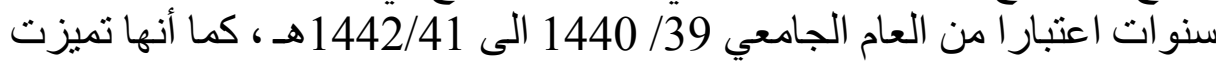

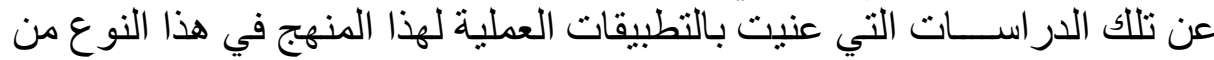

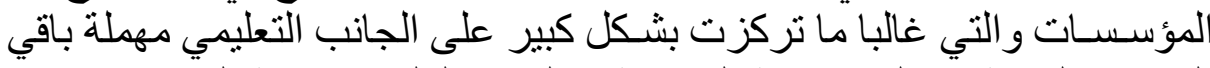

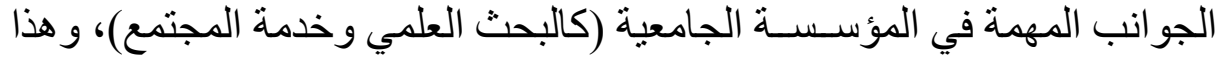

$$
\text { ما تم مر اعاته في آلدر اسة الحالية. }
$$

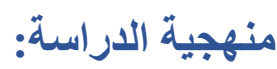

يمكن تناول منهجية الدراسة من خلال العناصر التالية:

1- أسلوب البحث المكتبي: من خلال الاطلاع على الكتب و الدوريات و الرسـائل

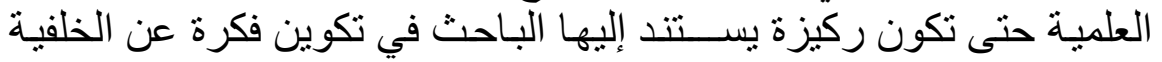

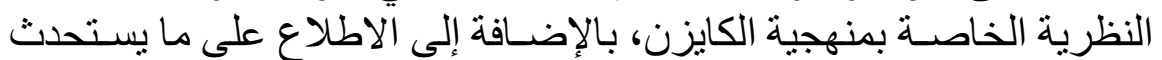

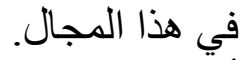

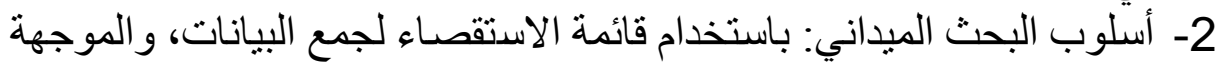

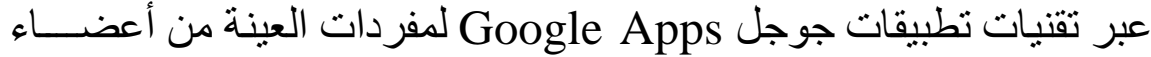

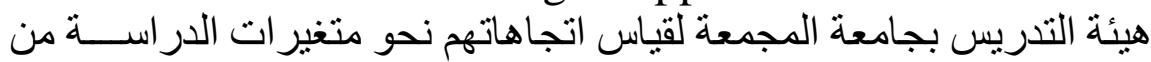

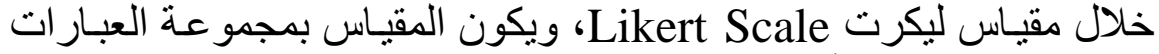

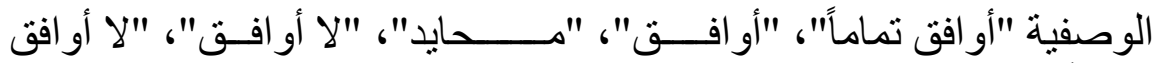

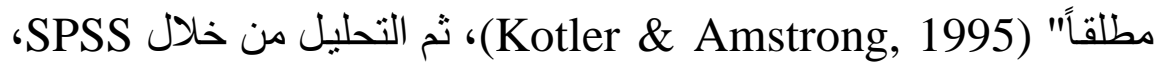

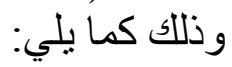
التحقق من درجة الصـدق و الثبات لـحتويات الاسـتبانة باســــدام معامل

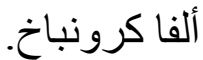




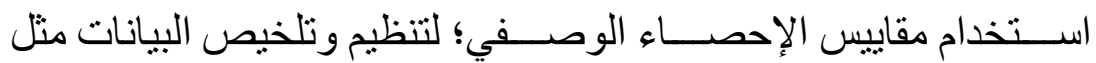

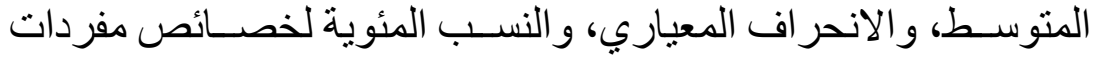

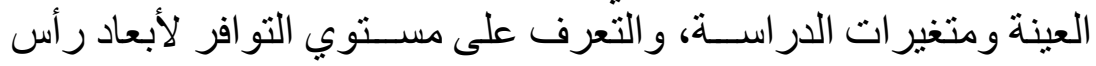
المال الفكري و التميز التنافسي.

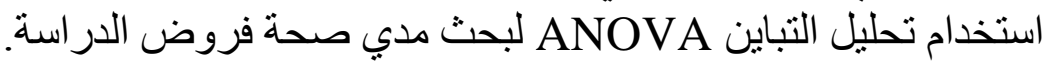

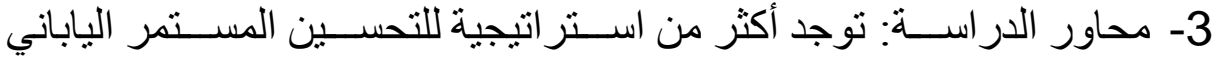
Kaizen

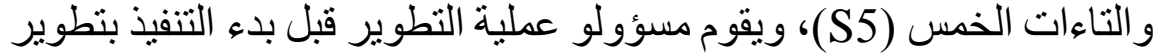

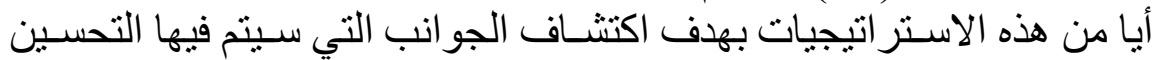

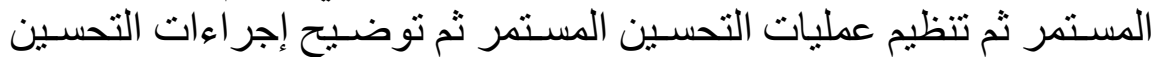

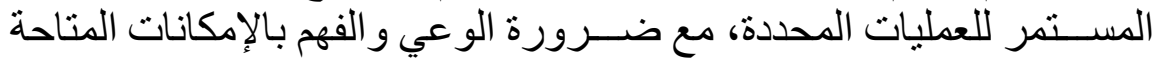

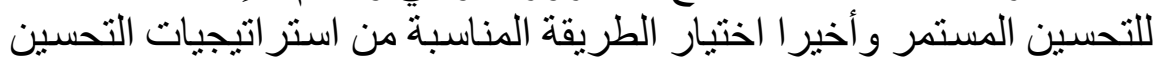

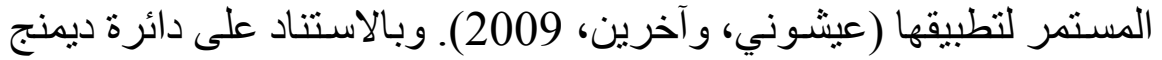

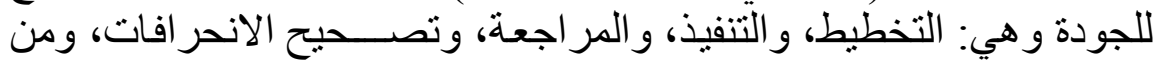

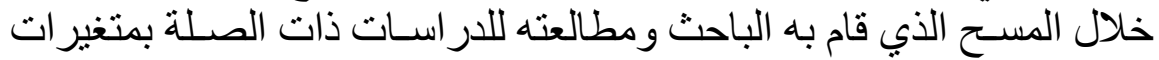

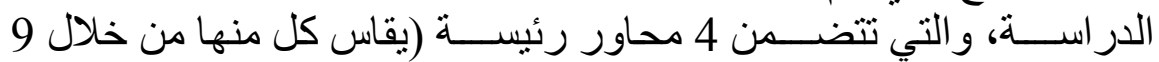

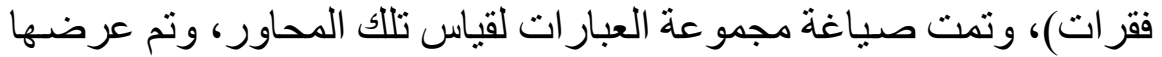

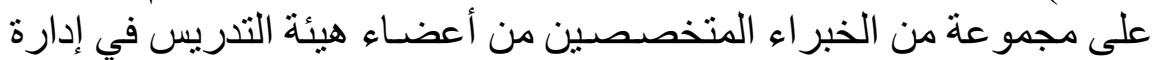

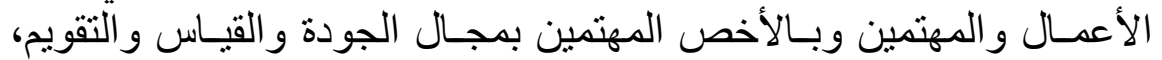

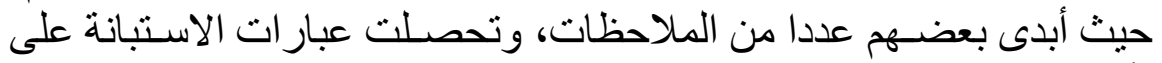

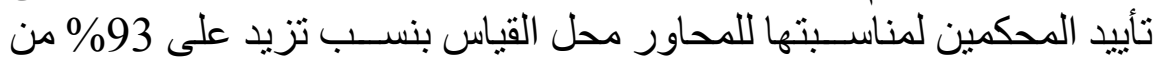

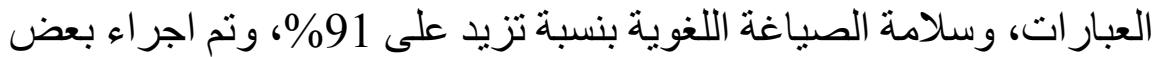

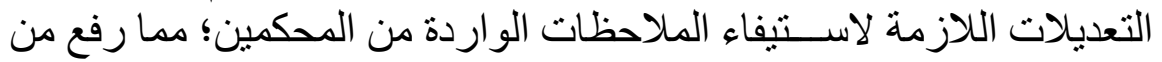
درجة مناسبة العبار ات ودقة صياغتهاء الاتها. مجتمع و عينة الدراسة: لغرض استطلاع الآراء حول متغير ات الدراسة

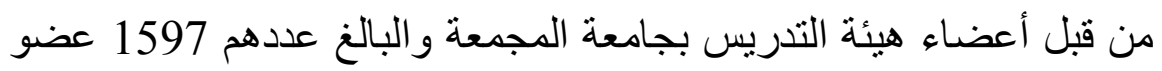
عام 2016/2015، حيث تضم الجامعة 13 كلية مختلفة تقدم 44 برنامجا دراسياً، وقد تم توزيع الاستبانات من خلال الرابط المعد لللك باستخدام

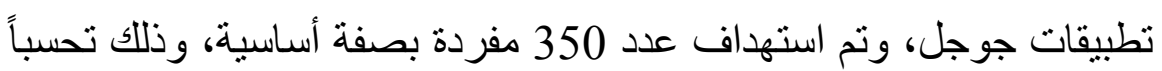
لعدم استجابة بعض المتنهدفين أو عدم صلاحية كافة الاستبانات للتحليل 
الاحصائي، وبلغت عدد الردود التي تم تفريغها وصالحة للتحليل الاحصائي بو اقع 326 مفردة، أي بنسبة 93.14\% من المستهدف.

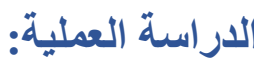

خصائص العينة

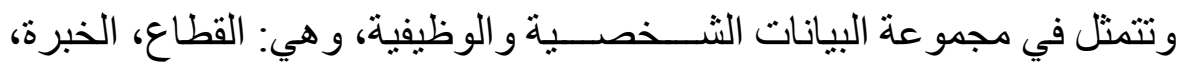

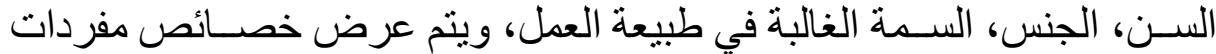

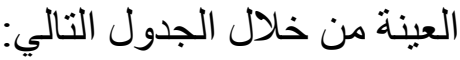

جدول (2) (2) - (2)

خصائص مفردات عينة الاراسة *

\begin{tabular}{|c|c|c|c|c|}
\hline الترتيب & $\%$ & العدد & الفئات & الخاصية \\
\hline 1 & 88.3 & 288 & الدر اسات الإنسانية & \multirow{4}{*}{ القطاع } \\
\hline 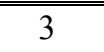 & 5.5 & 18 & العلوم التطبيقية & \\
\hline \multirow[t]{2}{*}{2} & 6.1 & 20 & الهندسة و الحاسب الآلي & \\
\hline & 100 & 326 & إجمالي & \\
\hline 1 & 69.0 & 225 & ذكر & \multirow{3}{*}{ 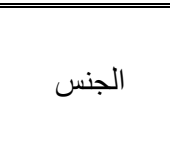 } \\
\hline \multirow[t]{2}{*}{2} & 31.0 & 101 & أنثى & \\
\hline & 100 & 326 & إجمالي & \\
\hline 1 & 29.4 & 96 & أقل من 35 سنة & \multirow{5}{*}{ 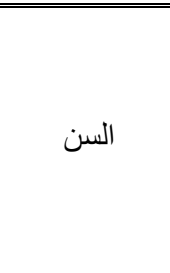 } \\
\hline 4 & 11.7 & 38 & من 35 إلى أقل من 45 سنة & \\
\hline 2 & 28.2 & 92 & من 45 الى 55 سنة & \\
\hline \multirow[t]{2}{*}{3} & 17.2 & 56 & 55 سنة فأكثر & \\
\hline & 100 & 326 & إجمالي & \\
\hline 3 & 17.2 & 56 & أقل من 3 سنوات & \multirow{4}{*}{ الخبرة } \\
\hline 1 & 62.0 & 202 & من 3 إلى أقل من 7 سنو ات & \\
\hline \multirow[t]{2}{*}{2} & 20.9 & 68 & من 7 سنو ات فأكثر & \\
\hline & 100 & 326 & إجمالي & \\
\hline 1 & 68.7 & 224 & ت ت ت ايس & \multirow{4}{*}{ طبيعة الوظيفة } \\
\hline 2 & 28.2 & 92 & تدريس و إداري & \\
\hline \multirow[t]{2}{*}{3} & 3.1 & 10 & قيادي و إداري & \\
\hline & 100 & 326 & إجمالي & \\
\hline
\end{tabular}

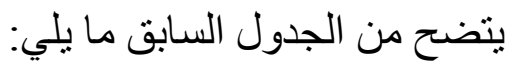


1- أن أكبر من نصف مفردات العينة من قطاع الدر اسـات الإنسانية و هم الغالبية

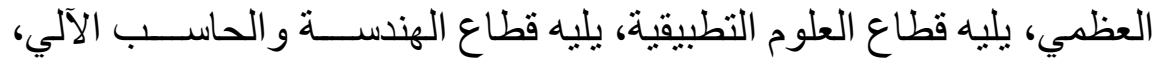

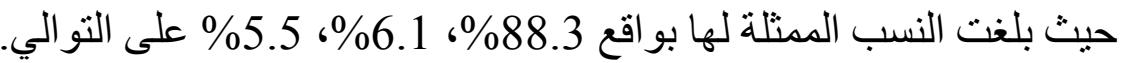

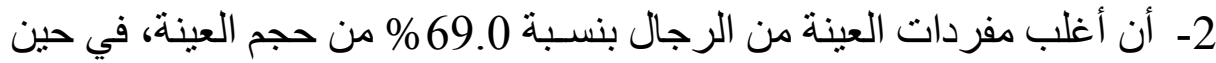

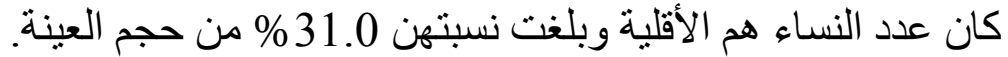

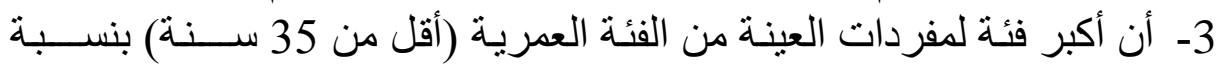

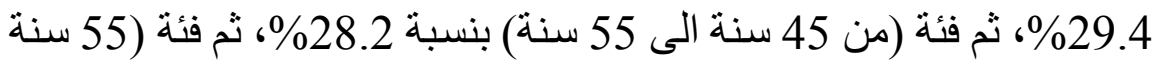

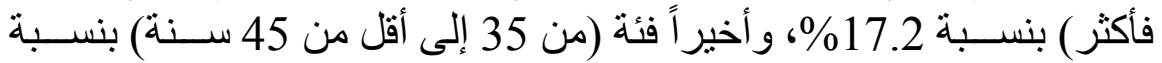
$\% 11.7$

4- أن أكبر فئة لدفردات العينـة من فئة الخبرة (من 3 إلى أقل من 7 ســـنوات)

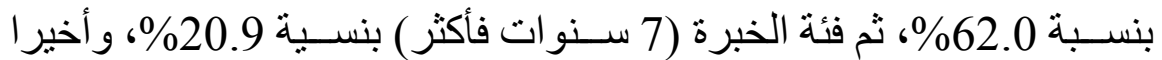

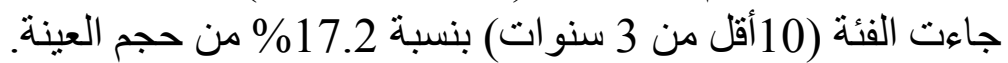

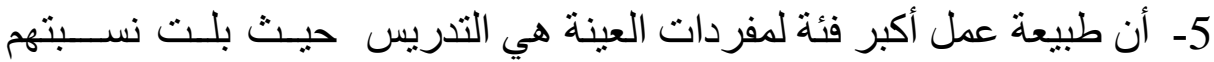

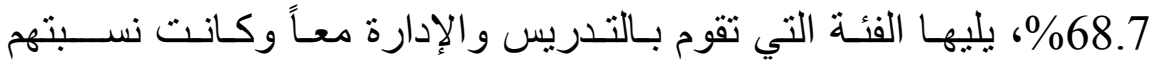
\%8.2\%، 28.7، أقلهم الفئة ذات الطابع الإداري و القيادي حيث كانت نسبتهم 3.1.

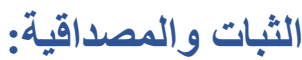

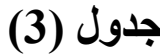

الثبات والمصداقية بين متغيرات القياس*

\begin{tabular}{|c|c|c|}
\hline ألفا & عدد العبار ات & المحور \\
\hline 0.766 & 9 & التخطيط \\
\hline 0.869 & 9 & التنفيذ \\
\hline 0.921 & 9 & المر اجعة \\
\hline 0.945 & 9 & تصحيح الانحر افات \\
\hline
\end{tabular}

*من إعداد الباحث وفقا لنتائج تحليل الاحصائي

وفقا لقيمة ألف كروبناخ السـالف الإثـارة اليها بالجدول السـابق و التي تتر اوح

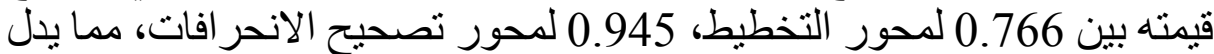
على ارتفاع قيمتها عن الحد 0.7، و أن قيمتها تتراوح بين المعقول و المرتفع. 
1- - مدى توافر مراحل تطبيق منهجية الكايزن - الوسط الحسابي والانحراف المعياري لبُعد التخطيط:

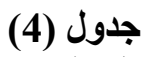

الوسط الحسابي والاتحر اف المعياري لعبارات بُعد التخطيط

\begin{tabular}{|c|c|c|c|}
\hline 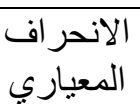 & الحسابي & ينت التخطبط في الجامعة: & r \\
\hline 0.62 & 3.88 & 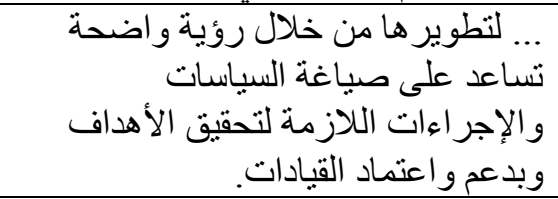 & 1 \\
\hline 0.80 & 3.33 & نموذجي ومنكامل. لتطوير مهارات القياديين بشكل & 2 \\
\hline 0.94 & 3.40 & بشكل نموذجي ومهنكامل. لتطاء أعضاء هيئة التدريس & 3 \\
\hline 0.81 & 3.27 & نموذجي و متكامل. لتطوير مهار موظفيها بشكل & 4 \\
\hline 0.84 & 3.85 & 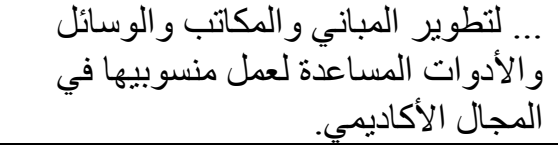 & 5 \\
\hline 0.85 & 3.44 & والبحتية. لتطوير المباتي و المساعدة لعمل المنظو و الوسائل & 6 \\
\hline 0.88 & 3.60 & 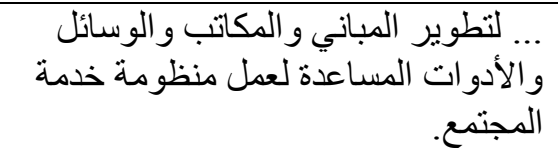 & 7 \\
\hline 0.82 & 3.97 & ... لتطوير نظم الاتصالات و التقنيات. & 8 \\
\hline 0.84 & 3.26 & نموذجي ومنكامل. لتطوير التحفيز لمنسو بيها بشكل & 9 \\
\hline 0.49 & 3.56 & متّوسط بُعد التخطيط & \\
\hline
\end{tabular}

يتضــح من الجدول السـابق مو افقة معظم أفر اد العينة على تو افر بعد التخطيط

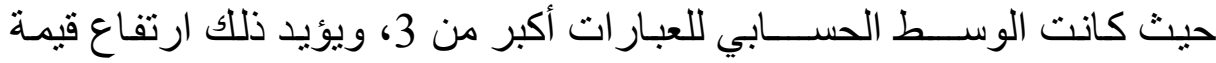

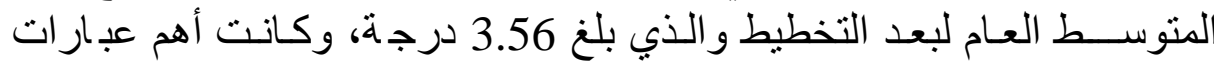

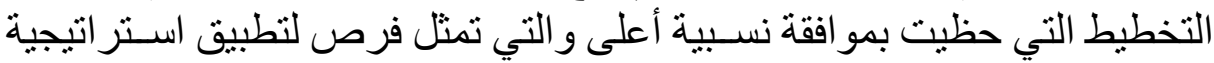
الكايزن في هذا البعد هي: يتم التخطيط في الجامعة ... . لتنطوير نظم الاتصالات و التقنيات، وقيمتها 3.97. 
• لتطوير ها من خلال رؤية و اضحة تساعد على صياغة السياسات و الإجر اءات اللازمة لتحقيق الأهداف وبدعم و اعتماد القيادات، وقيمتها .3.88 لتطوير المباني و المكاتب و الوسائل و الأدو ات المساعدة لعمل منسو بيها في المجال الأكاديمي، وقيمتها أما عبار ات التخطيط التي تمثل نالت أقل درجات المو افقة فهي: ينم التخطيط في

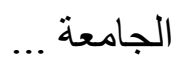

لتطوير بر امج التحفيز لمنسو بيها بشكل نموذجي ومتكامل، وقيمتها 3.26.

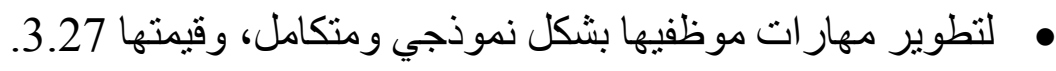

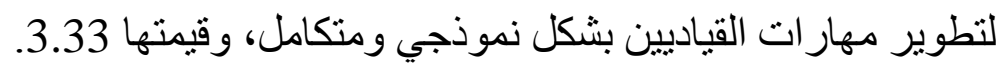
- الوسط الحسابي والانحراف المعياري لبُعد التنقيذ:

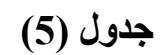

الوسط الحسابي والانحراف المعياري لعبارات بُعد التنفيذ

\begin{tabular}{|c|c|c|c|}
\hline 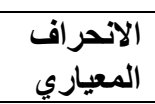 & الوسطي & تعمل الجامعة على تنفيذ خطة تطوير: & م \\
\hline 0.84 & 3.57 & .... السياسات و الاجر اءات بصفة عامة. & 1 \\
\hline 0.74 & 3.38 & .... مهار ات القياديين. & 2 \\
\hline 0.76 & 3.61 & ... مهار ات أعضاء هيئة التدريس. & 3 \\
\hline 0.77 & 3.38 & .... مهار ات الموظفين. & 4 \\
\hline 0.90 & 3.71 & المنظومة التعليمية. المباني و المكاتب والوسائل و الأدوات المساعدة لعمل & 5 \\
\hline 1.00 & 3.48 & المنظومة البحثية. المباتب و الوسائل و الأدوات المساعدة لعمل & 6 \\
\hline 0.88 & 3.54 & 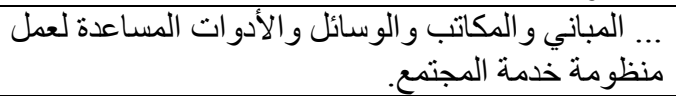 & 7 \\
\hline 0.79 & 3.82 & ... نظم الاتصالات و التقنبات. & 8 \\
\hline 0.87 & 3.41 & ... برامج التحفيز لمنسو بيها. & 9 \\
\hline 0.59 & 3.55 & متوسط بُعد التنفيذ & \\
\hline
\end{tabular}

يتضـــح من الجدول الســابق مو افقة معظم أفر اد العينة على تو افر بعد التخطيط

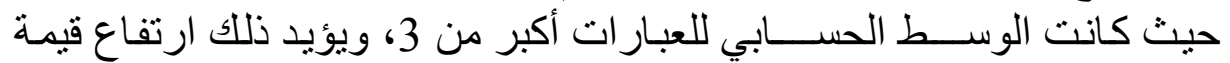

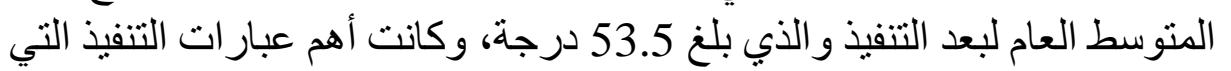

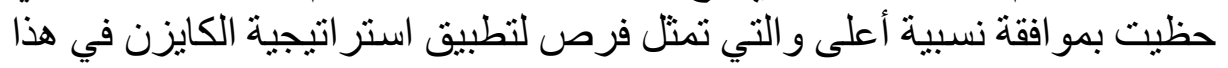
البعد هي: تعمل الجامعة على تنفيذ خطة تطوير .... نظم الاتصالات و التقنيات، وقيمتها 3.82. 
المباني و المكاتب و الوسائل و الأدو ات المساعدة لعمل المنظومة التعليمية،

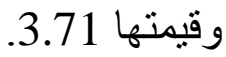

مهار ات أعضاء هيئة التدريس، وقيمتها 3.61.

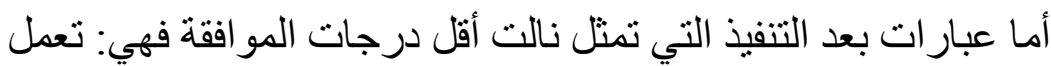

الجامعة على تنفيذ خطة تطوير ل...

مهار ات القياديين، وقيمنها 3.38.

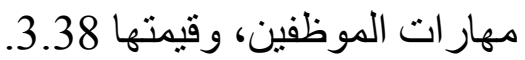

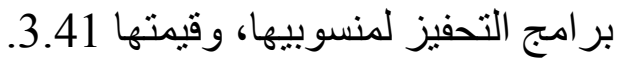

- الوسط الحسابي والاتحر اف المعياري لُبُّل المراجعة:

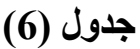

الوسط الحسابي والانحر اف المعياري لعبارات بُعد المراجعة

\begin{tabular}{|c|c|c|c|}
\hline 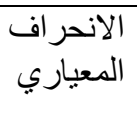 & الوسط الحسابي & تينم فحص (مر اجعة) الجامعة لمؤشر ات أداء خطة & r \\
\hline 0.75 & 3.58 & عامة وبشكل دوري. الخطياسات الموضو عة بعد تتفيذها بصفة & 1 \\
\hline 0.75 & 3.44 & ... مهار ات القياديين عقب تتفيذ الخطة بشكل دوري. & 2 \\
\hline 0.81 & 3.54 & بشكل دوري. مهار ات أعضاء هيئة التدريس عقب تتفيذ الخطة & 3 \\
\hline 0.80 & 3.43 & ... مهار ات الموظفين عقب تنفيذ الخطة بشكل دوري. & 4 \\
\hline 0.88 & 3.45 & 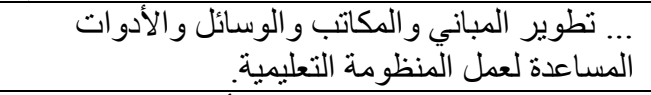 & 5 \\
\hline 0.83 & 3.48 & 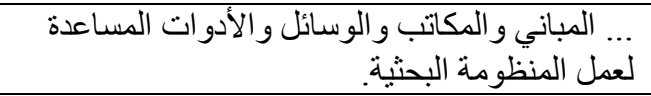 & 6 \\
\hline 0.79 & 3.61 & لعمل لمنظومة خدمة المبانب و الوسنائل و الأدوات المساعدة. & 7 \\
\hline 0.85 & 3.56 & ا.... نظم الاتصالات و التقنيات. & 8 \\
\hline 0.84 & 3.30 & .... بر امج التحفيز لمنسوبيها. & 9 \\
\hline 0.64 & 3.49 & متوسط بُعد المراجعة & \\
\hline
\end{tabular}

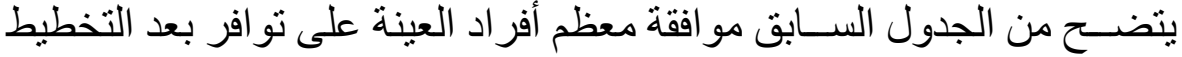

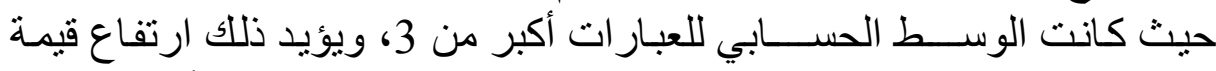

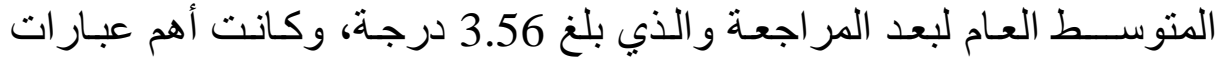

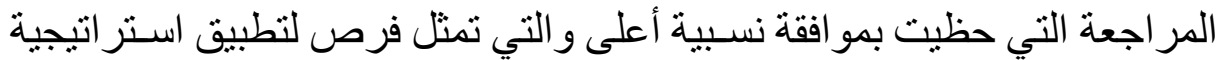

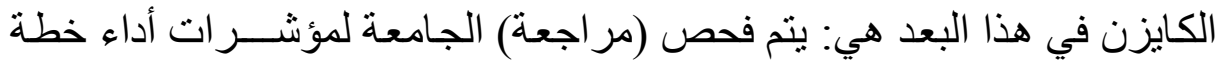
نطوير ....

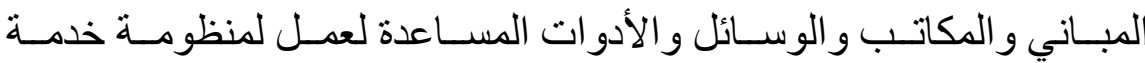

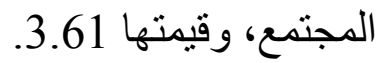




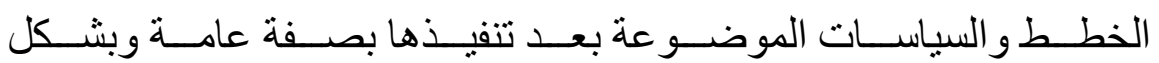

دوري، وقيمتها

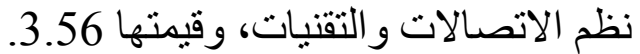

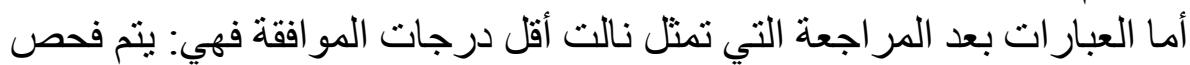

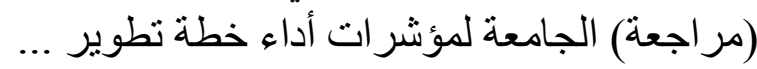

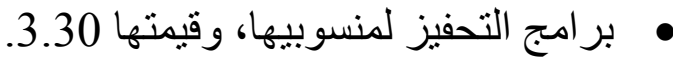

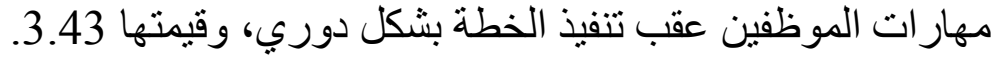

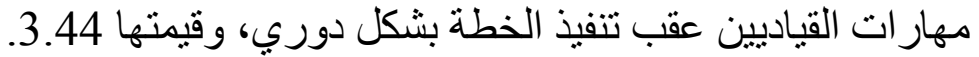

- الوسط الحسابي والانحر اف المعياري لُبُّد تصحيح الانحر افات:

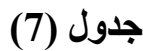

الوسط الحسابي والانحراف المعياري لعبارات بُد تصحيح الانحرافات

\begin{tabular}{|c|c|c|c|}
\hline الالنحرياف & الوسط الحسابي & وفتب تصائحيح الانحر افأن: في حالة عدم المطابقة بين المنفذ و المخطط & \\
\hline 0.86 & 3.34 & . السياسـات و الإجر اءات بصفة عامة. & 1 \\
\hline 0.77 & 3.26 & تطوير مهار ات القياديين. & 2 \\
\hline 0.76 & 3.31 & تطوير مهار ات أعضاء هيئة التدريس. & 3 \\
\hline 0.65 & 3.19 & ... تطوير مهارات الموظفين. & 4 \\
\hline 0.77 & 3.32 & المنظومة التعليمئي. & 5 \\
\hline 0.73 & 3.21 & المنظومة البحثية... تطوير و المكاتب و الوسائل و الأدوات المساعدة لعمل & 6 \\
\hline 0.62 & 3.36 & منظومة خدمة المجتمع. ... تطوير المباني والمكب والوسائل و الأدو ات المساعدة لعمل & 7 \\
\hline 0.68 & 3.52 & ... تطوير نظم الاتصالات و التقنيات. & 8 \\
\hline 0.80 & 3.21 & تطوير بر امج التحفيز لمنسو بيها. & 9 \\
\hline 0.62 & 3.20 & سط بُعد تصحيح الانحر افات & \\
\hline
\end{tabular}

يتضــح من الجدول السـابق مو افقة معظم أفر اد العينة على نو افر بعد تصـــيح

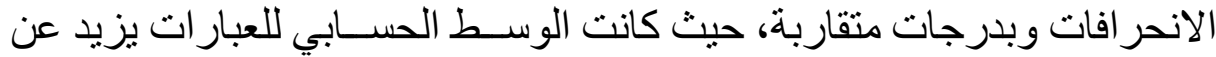

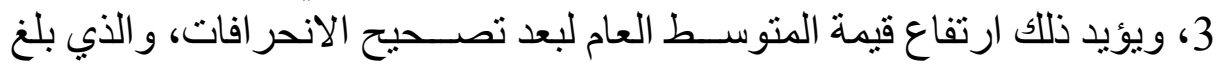

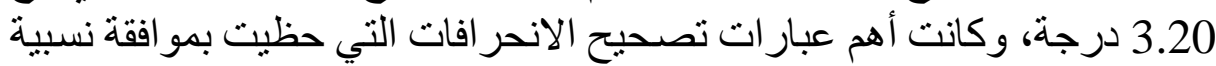
أعلى والتي تمثل فرص التطبيق استر اتيجية الكايزن في هذا التئي البعد هي: يتم تصديح

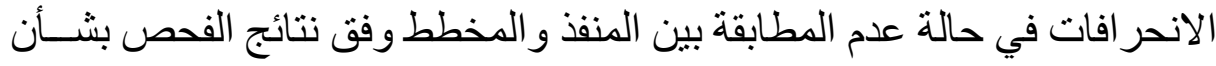

تطوير نظم الاتصالات و التقنيات، وقيمتها 3.52. 


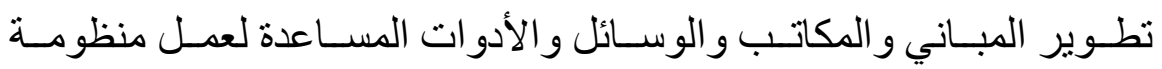
خدمة المجتمع، وقيمتها 3.36.

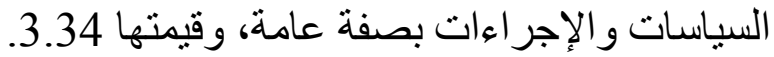

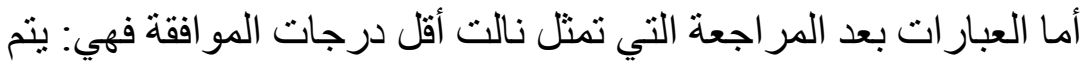
تصحيح الانحر افات في حالة عدم المطابقة بين المنفذ و المخطط وفق نتائج

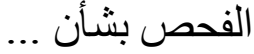

تطوير مهار ات الموظفين، وقيمتها 3.19.

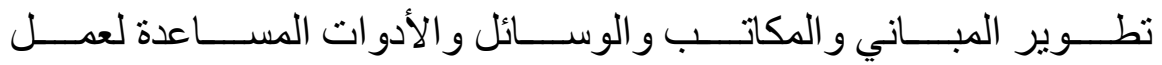

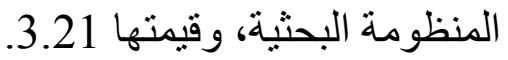

تطوير بر امج التحفيز لمنسوبيها، وقيمتها 3.21.

2- مقترحات التظوير وأولويات التحسين جدول (8) (8)

مقترحات التطوير وأولويات التحسين وفق التكرار المتجمع الصاعد

\begin{tabular}{|c|c|c|c|c|c|c|c|c|c|}
\hline $\begin{array}{c}9 \\
\% \\
\end{array}$ & $\begin{array}{l}8 \\
\%\end{array}$ & $\begin{array}{l}7 \\
\%\end{array}$ & $\begin{array}{l}6 \\
\%\end{array}$ & $\begin{array}{l}5 \\
\%\end{array}$ & $\begin{array}{c}4 \\
\% \\
\%\end{array}$ & $\begin{array}{l}3 \\
\%\end{array}$ & 0 & $\begin{array}{l}1 \\
\%\end{array}$ & ونسبتها المئوية \\
\hline 100.0 & 93.9 & 90.8 & 84.7 & 82.5 & 73.6 & 57.7 & 44.8 & 29.4 & السياسات والإجراءات بصفة عامة. \\
\hline 100.0 & - & 92.3 & 89.3 & 83.1 & 74.2 & 60.7 & 39.9 & 25.2 & تطوير مهار ات القياديين. \\
\hline 100.0 & - & 96.9 & 91.7 & 89.3 & 77.9 & 66.9 & 58.6 & 39.9 & تطوير مهار ات أعضاء هيئة الندريس \\
\hline 100.0 & - & 93.9 & 90.8 & 85.9 & 74.8 & 60.7 & 45.1 & 29.1 & تطوير مهار ات الموظفين. \\
\hline 100.0 & 94.8 & 89.3 & 86.2 & 80.7 & 69.3 & 57.1 & 42.3 & 21.8 & 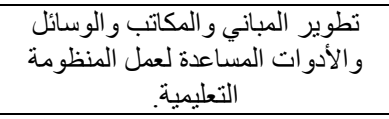 \\
\hline 100.0 & 96.9 & 93.9 & 88.3 & 86.2 & 74.2 & 65.6 & 47.9 & 27.0 & 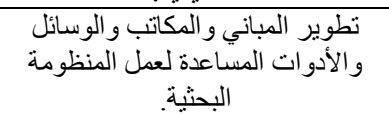 \\
\hline 100.0 & 93.9 & 88.3 & 85.3 & 82.8 & 71.8 & 63.2 & 42.9 & 15.6 & 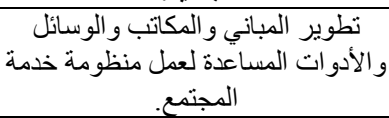 \\
\hline 100.0 & 94.8 & 85.9 & & 82.8 & 74.2 & 60.7 & 43.6 & 21.2 & تطوير نظم الاتصالات و الثقنيات. \\
\hline & & 96.9 & 90.8 & 87.7 & 74.8 & 68.7 & 6 & 50.9 & 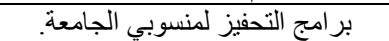 \\
\hline
\end{tabular}

يتبين من الجدول السابق أن أكثر المجالات التي تحتاج الى تطوير كما يلي:

حصـلت برامج التحفيز لمنســوبي الجامعة على أكبر نســـة من أفر اد العينة

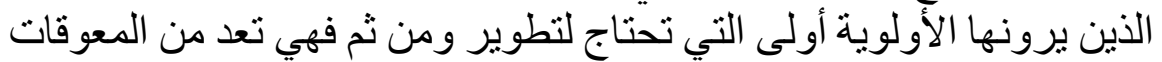

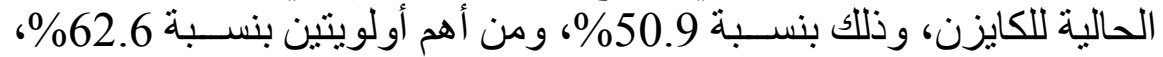

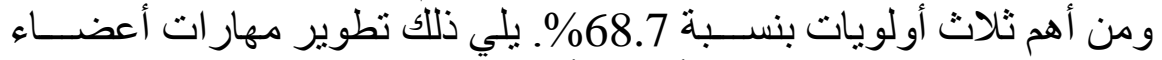

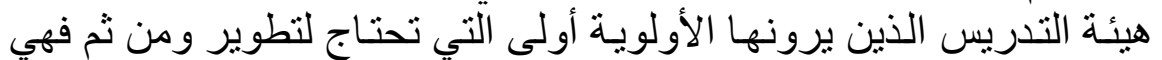

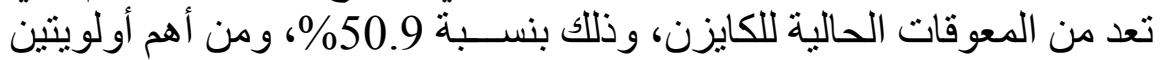

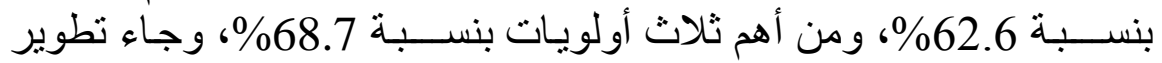

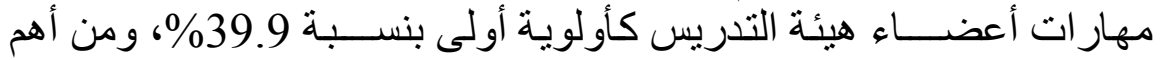

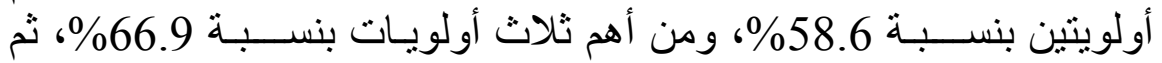




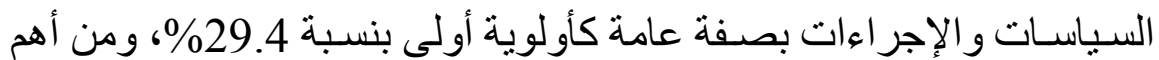

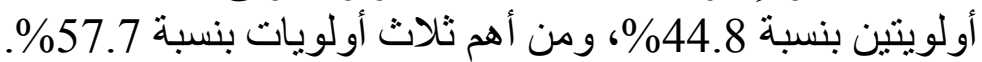

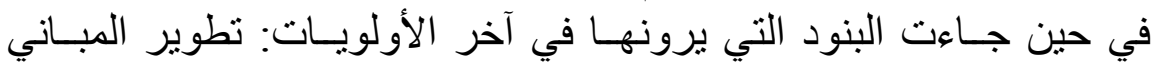

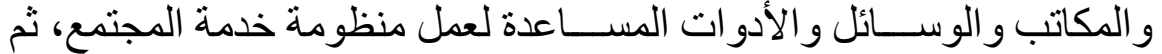

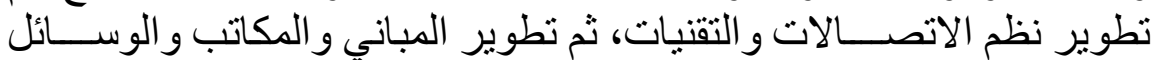

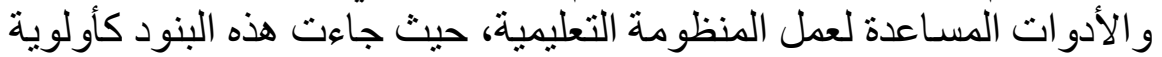

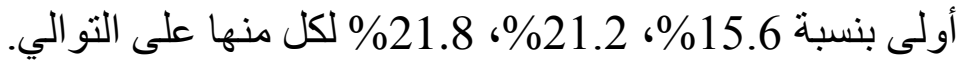

3- بيان دائرة الكايزن لكل مجال على حدة:

يمكن التعرض لدائرة الكايزن لكل مجال على عدة على كما يلي:

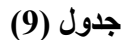

\begin{tabular}{|c|c|c|c|c|c|}
\hline الانحرافات & المراجعة & التففيذ & التخطيط & المجال & b \\
\hline 3.34 & 3.58 & 3.57 & 3.88 & السياسات والإجر اءات بصفة & 1 \\
\hline 3.26 & 3.44 & 3.38 & 3.33 & تطوير مهار ات القياديين. & 2 \\
\hline 3.31 & 3.54 & 3.61 & 3.40 & تطوير مهارات أعضاء هيئة & 3 \\
\hline 3.19 & 3.43 & 3.38 & 3.27 & تطوير مهار ات الموظفين. & 4 \\
\hline 3.32 & 3.45 & 3.71 & 3.85 & 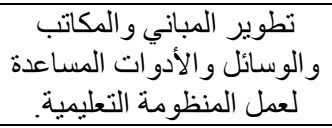 & 5 \\
\hline 3.21 & 3.48 & 3.48 & 3.44 & 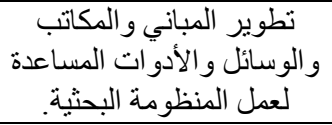 & 6 \\
\hline 3.36 & 3.61 & 3.54 & 3.60 & 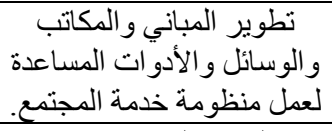 & 7 \\
\hline 3.52 & 3.56 & 3.82 & 3.97 & تطوير نظم الاتصالات & 8 \\
\hline 3.21 & 3.30 & 3.41 & 3.26 & بر امج التحفيز لمنسوبي & 9 \\
\hline 3.20 & 3.49 & 3.55 & 3.56 & المتوسط & \\
\hline
\end{tabular}

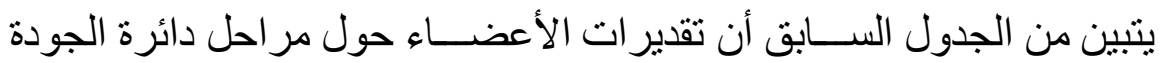

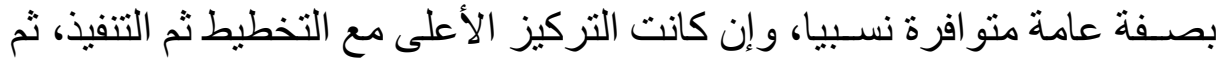

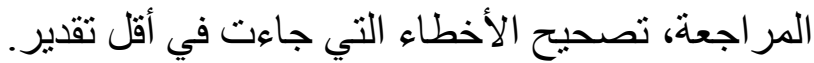

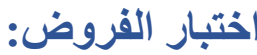

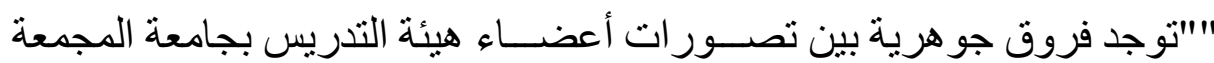

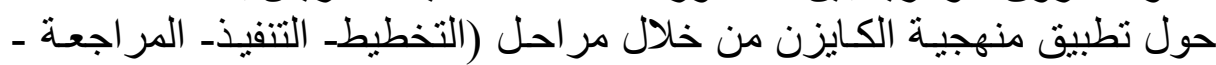
التحسين) وفقا لخصائص العينة (الخبرة- العمر - نوع من الوظيفة ـ الجنس)". 
ويتم بحث هذا الفرض من خلال أربعة فروض فرعية على النحو التالي:

1- الفروق بين أبعاد دائرة الجودة وفقاً للخبرة

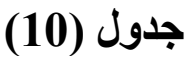

مدى وجود فروق جوهرية بين أبعاد دائرة الجودة لدى أعضاء هيئة التدريس

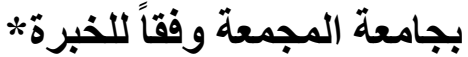

\begin{tabular}{|c|c|c|c|c|c|}
\hline تصحيح الأخطاء & المر اجعة & التنفيذ التني & التخطيط & \multicolumn{2}{|c|}{ الخبرة بجامعة المجمعة } \\
\hline 3.65 & 3.84 & 3.61 & 3.45 & المتوسط & \\
\hline 0.65 & 0.63 & 0.51 & 0.68 & الانحر افت المعياري & اقل من 3 سنوات \\
\hline 3.30 & 3.51 & 3.65 & 3.69 & المتوسط & \\
\hline 0.51 & 0.60 & 0.59 & 0.44 & الانحر اف المعياري & يى اقل من 7 سنوات \\
\hline 3.02 & 3.15 & 3.18 & 3.24 & المتوسط & \\
\hline 0.73 & 0.58 & 0.50 & 0.20 & الانحر اف المعياري & 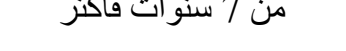 \\
\hline 20.35 & 17.96 & 27.63 & 27.63 & & $\mathrm{~F}$ \\
\hline .000 & .000 & .000 & .000 & & مستوى | (مست \\
\hline
\end{tabular}

يتضح من الجدول السابق وجود فروق جو هرية بين تقدير ات مفردات العينة

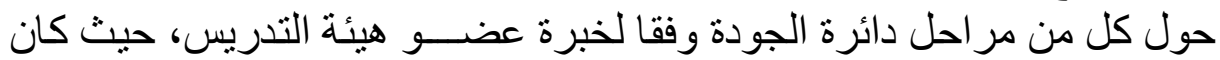

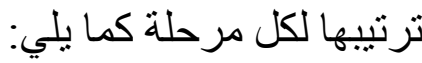

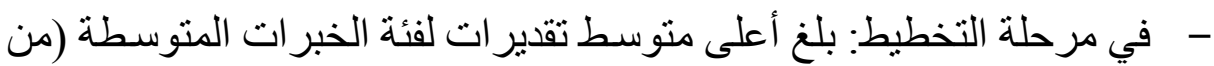

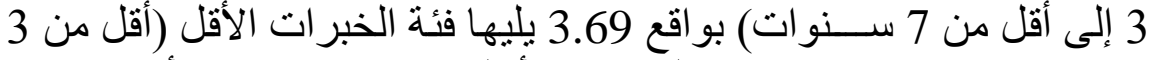

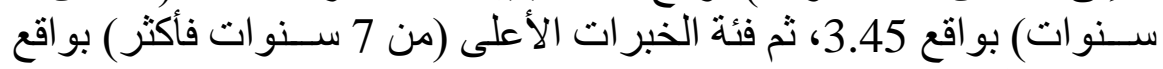
3.24. وبلغت قيمة

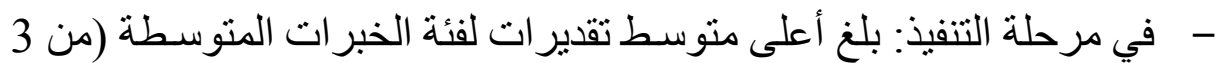

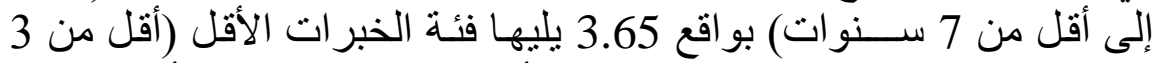

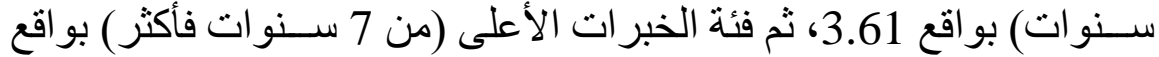

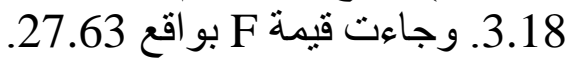

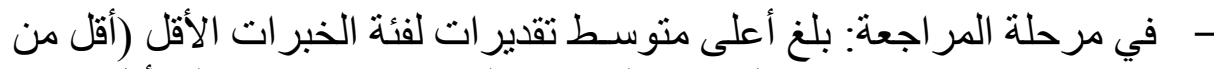

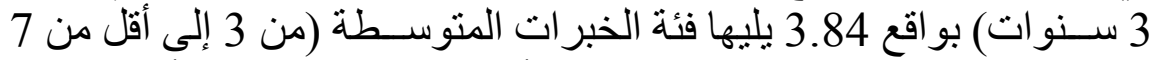

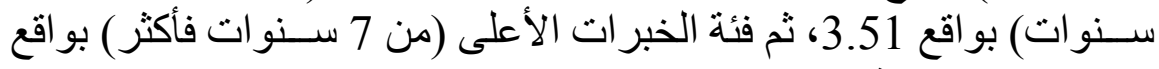

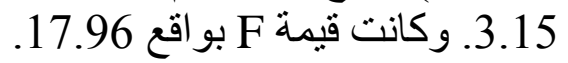

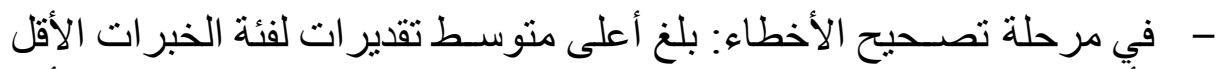

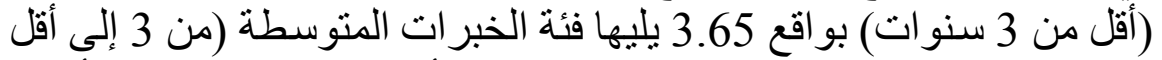

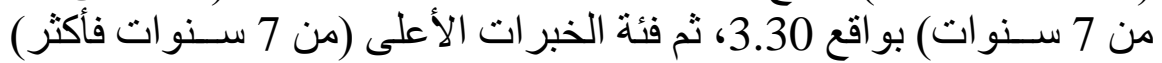

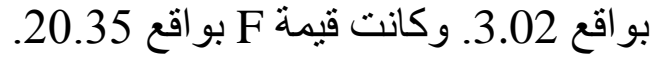


2- القروق بين أبعاد دائرة الجودة وفقاً للعمر

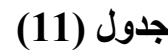

مدى وجود فروق جوهرية بين أبعاد دائرة الجودة لاى أعضاء هيئة التدريس بجامعة

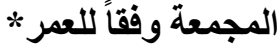

\begin{tabular}{|c|c|c|c|c|c|}
\hline تصحيح & المر اجعة & التنفيذ & التخطيط & \multicolumn{2}{|c|}{ الخبرة بجامعة المجمعة } \\
\hline 3.28 & 3.41 & 3.46 & 3.43 & المتوسط & \multirow[b]{2}{*}{ أقل من 35 سنة } \\
\hline 0.53 & 0.56 & 0.42 & 0.53 & المعياري & \\
\hline 2.73 & 3.22 & 3.21 & 3.20 & المتوسط & \multirow{2}{*}{ من 35 إلى أقل من } \\
\hline 0.83 & 1.11 & 1.14 & 0.54 & الالانحر افي & \\
\hline 3.45 & 3.62 & 3.69 & 3.72 & المتوسط & \multirow[b]{2}{*}{ من 45 الى 55 سنة } \\
\hline 0.45 & 0.38 & 0.46 & 0.42 & الإنحراف & \\
\hline 3.36 & 3.63 & 3.49 & 3.61 & المتوسط & \multirow[b]{2}{*}{55 سنة فاككثر } \\
\hline 0.41 & 0.35 & 0.34 & 0.30 & الالنحر اف & \\
\hline 11.55 & 3.92 & 7.44 & 12.07 & \multicolumn{2}{|c|}{$\mathrm{F}$} \\
\hline 000 & .004 & .000 & .000 & & مستوى ال \\
\hline
\end{tabular}

* من إعداد الباحث وفقا لنتائج تحليل الاحصائي

يتضـح من الجدول السـابق وجود فروق جو هرية بين تقدير ات مفردات العينة حول كل من مر احل دائرة الجودة وفقا لعمر عضـــــ هيئة التدريس، حيث كان ترتيبها لكل مرحلة كما يلي:

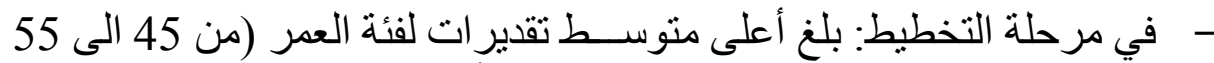

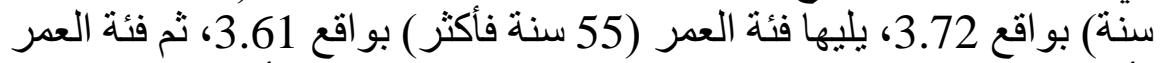

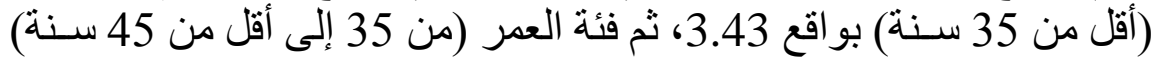

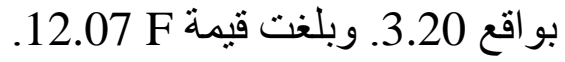

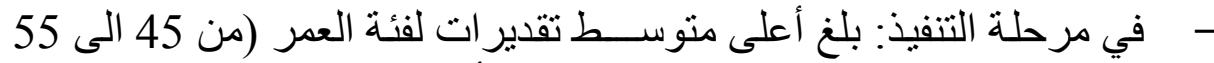

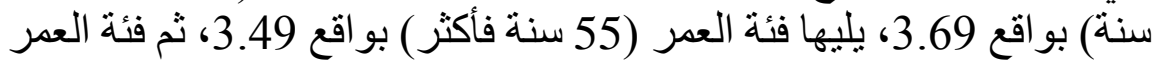

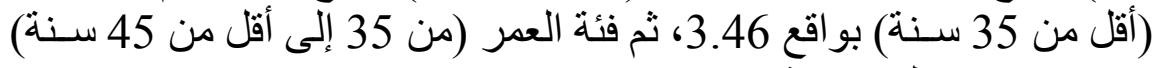
بو اقع 3.21.

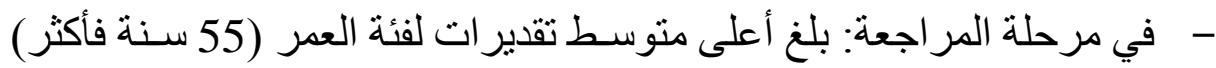

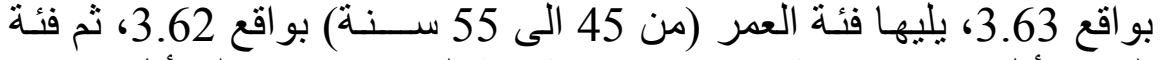

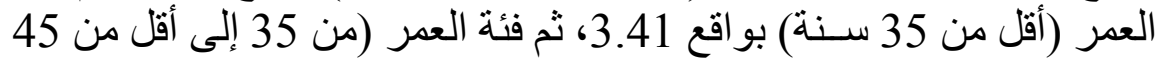

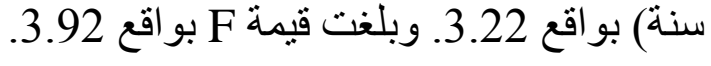

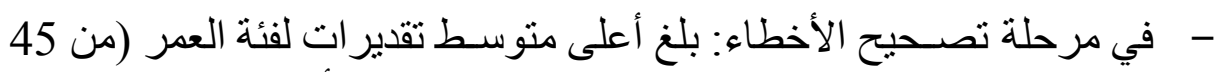

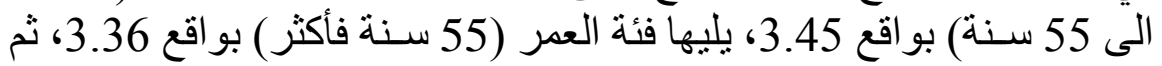




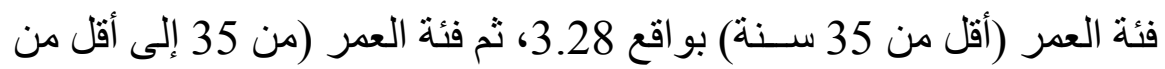

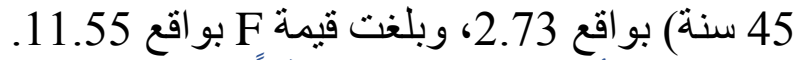

3- الفروق بين أبعاد دائرة الجودة وفقاً للجنس

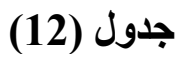

مدى وجود فروق جوهرية بين أبعاد دائرة الجودة لاى أعضاء هيئة التدريس بجامعة

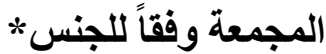

\begin{tabular}{|c|c|c|c|c|c|}
\hline تصحيح الأخطاء & المر اجعة & آلتنفيذ & التخطيط & رة بجامعة المجمعة & \multirow{3}{*}{ ن أكر } \\
\hline 3.32 & 3.49 & 3.51 & & المتوسط & \\
\hline 0.62 & 0.58 & 0.55 & & الانحر اف المعياري & \\
\hline 3.27 & 3.48 & 3.63 & & المتوسط & \multirow{2}{*}{ أنثى } \\
\hline 0.61 & 0.75 & 0.67 & 0.41 & الانحر اف المعياري & \\
\hline 0.49 & 0.01 & 3.01 & 5.97 & \\
\hline .485 & .906 & .084 & .015 & \multicolumn{2}{|l|}{ مستوى المعنوية } \\
\hline
\end{tabular}
*من إعداد الباحث وفقا لنتائج تحليل الاحصائي

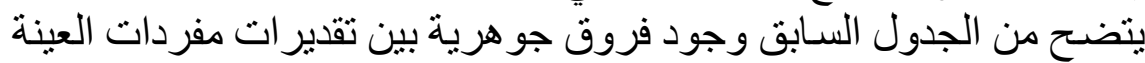

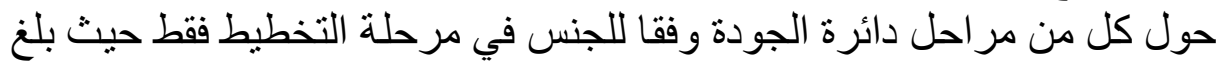

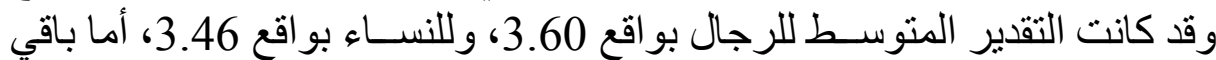

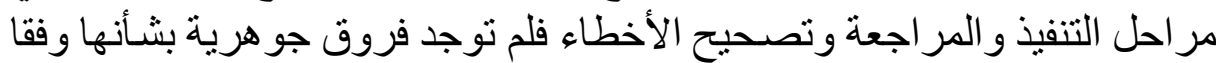

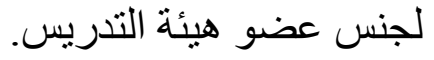

4- الفروق بين أبعاد دائرة الجودة وفقاً لطبيعة الوظيفة

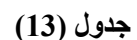

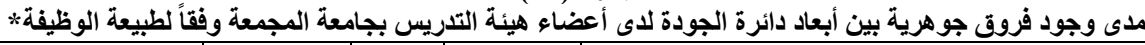

\begin{tabular}{|c|c|c|c|c|c|}
\hline تصحيح الأخطاء & المراجعة & التنفيذ & التخطيط & معة المجمعة & الخبرة بج \\
\hline 3.33 & 3.56 & 3.63 & 3.66 & المتوسط & \multirow[b]{2}{*}{ ل ريس } \\
\hline 0.61 & 0.61 & 0.61 & 0.42 & الانحر اف المعياري & \\
\hline 3.19 & 3.22 & 3.34 & 3.36 & المتوسط & \multirow{2}{*}{ تدريس و إداري } \\
\hline 0.64 & 0.61 & 0.52 & 0.59 & الانحر اف المعياري & \\
\hline 3.67 & 4.33 & 3.44 & 3.11 & المنوسط & \multirow{2}{*}{ قيادي و إداري } \\
\hline 0.00 & 0.00 & 0.00 & 0.00 & الانحر اف المعياري & \\
\hline 3.71 & 21.17 & 8.67 & 18.26 & \multicolumn{2}{|l|}{$\Gamma$} \\
\hline & .004 & .000 & 00 & & 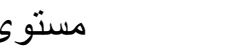 \\
\hline
\end{tabular}

*من إعداد الباحث وفقا لنتائج تحليل الاحصائي

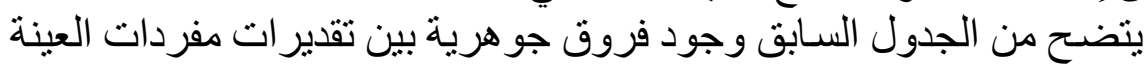

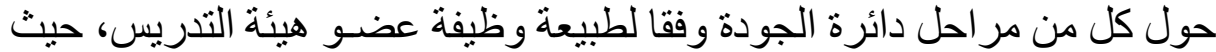

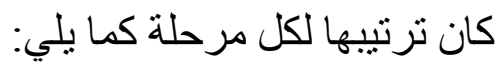




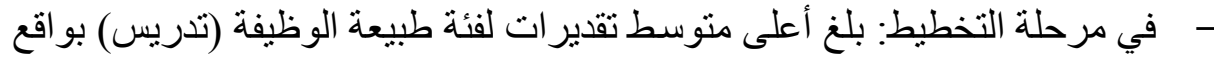

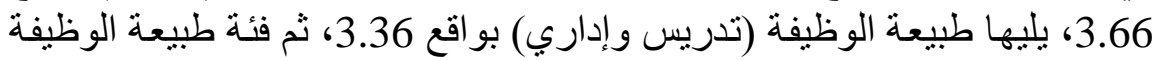

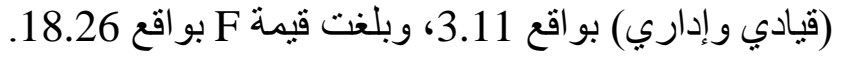

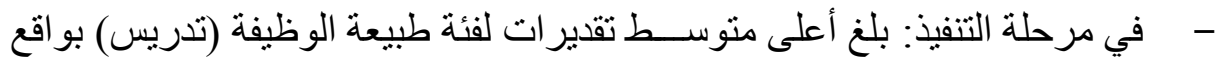

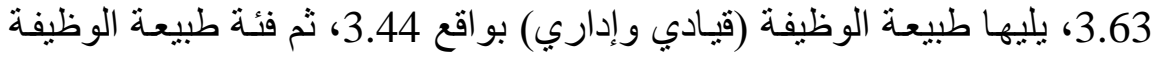

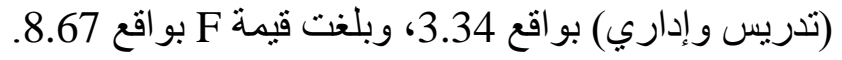

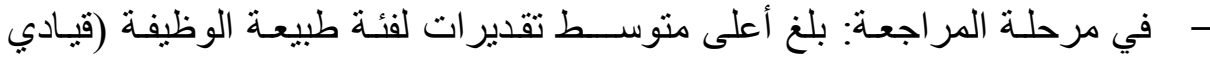

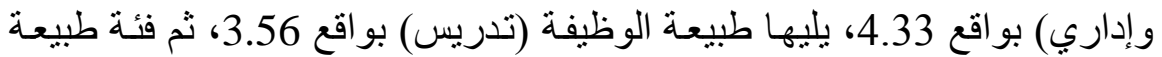
الوظيفة (تدريس و إداري) بو اقع 3.22، وبلغت قيمة F بو اقع 21.17.

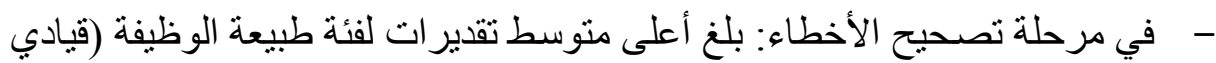

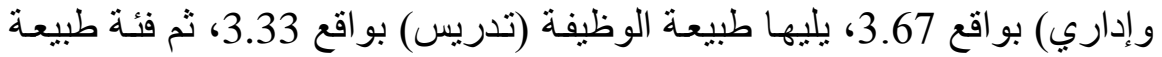

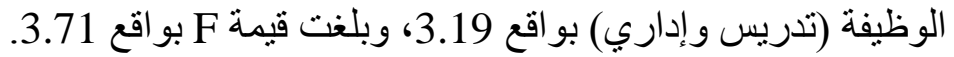
التوصيات

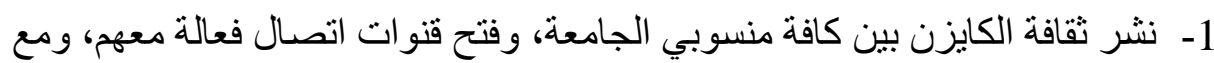
الجامعات النظيرة و المتميزة وبخطط تهدف لفعاليات احتر افية.

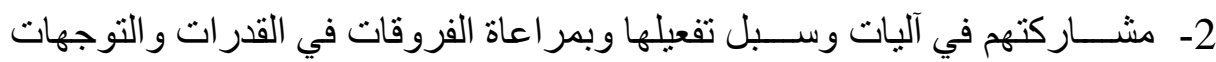

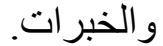
3- التركيز على آليات تتفيذ المهام بأفضل السبل في طريق التحسين بمقارنة كل ما هو

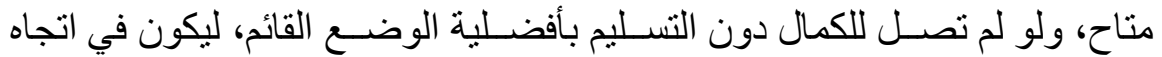

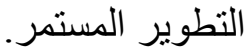

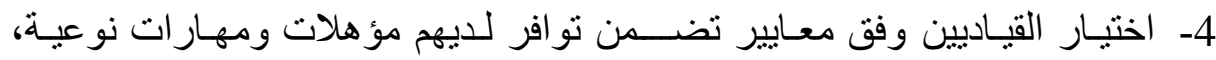

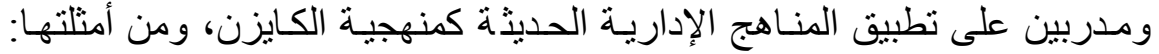

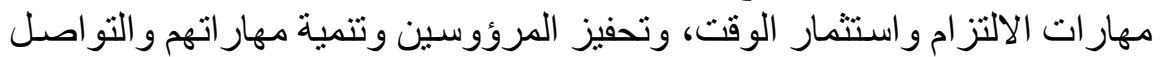

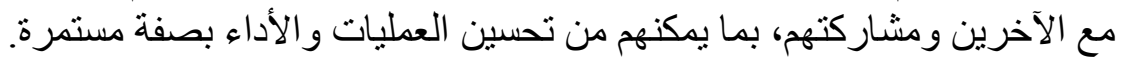

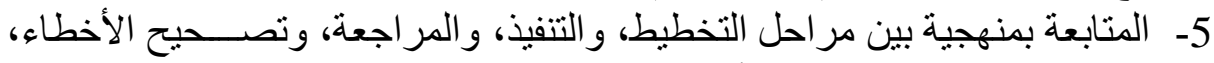

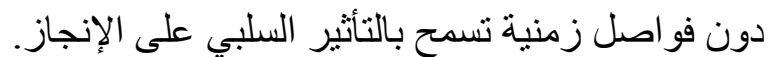
6- على المسؤولين مر اعاة الأولويات التي تحتاج لتطوير من وجهة نظر الإنها أعضـاء هيئة

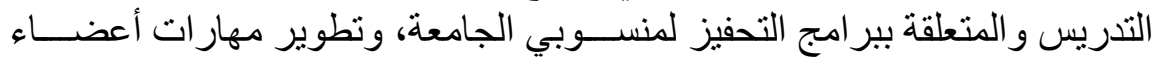

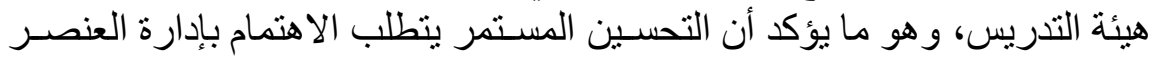

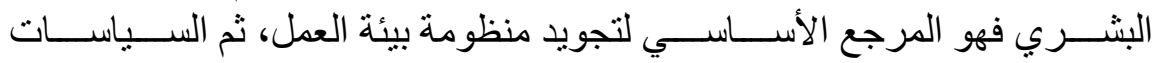
و الإجر اءات المتبعة في الجامعة بصفة الئة عامة.

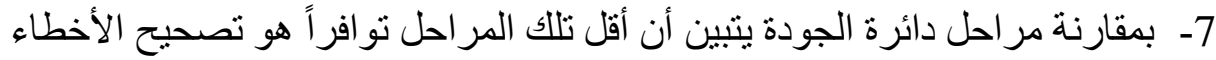

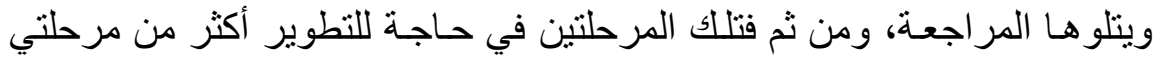
التخطبط و التنفيذ.

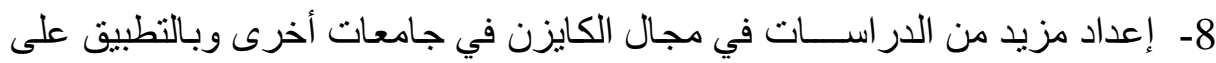
فئـات بخلاف أعضـــــاء هيئة التدريس من الموظفين والطلاب أو المزج بين تلك فئك 


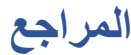

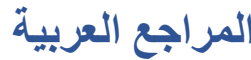

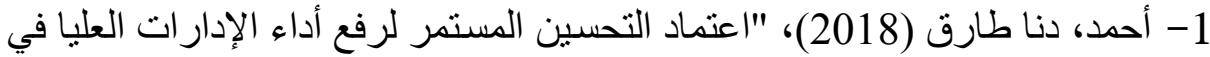

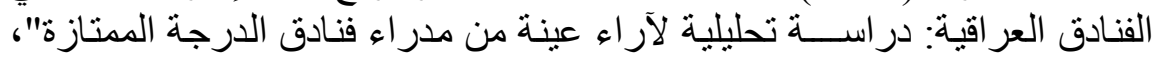

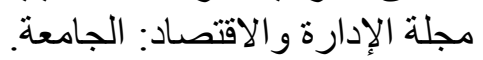

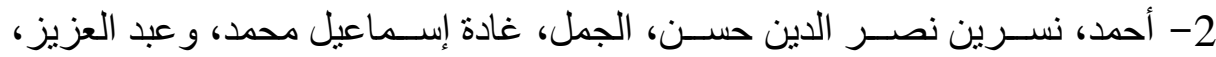

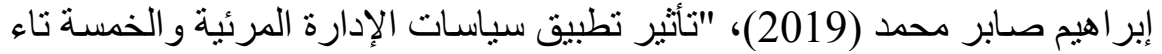

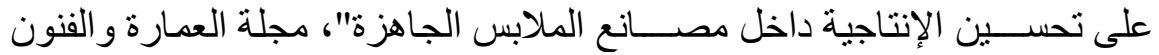

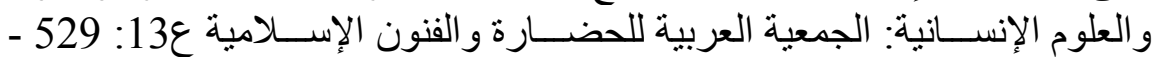
.544

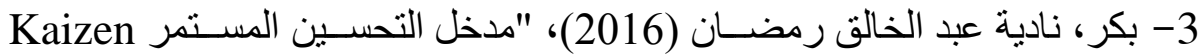

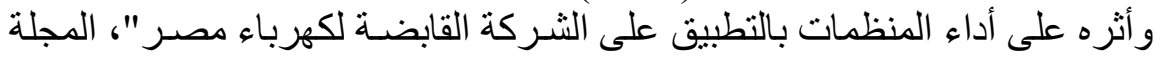

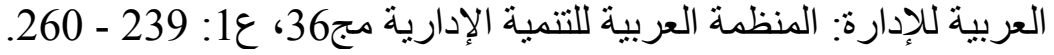

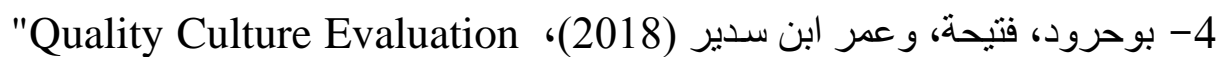
in Algerian Companies: An Empirical Study"

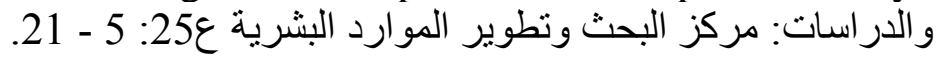

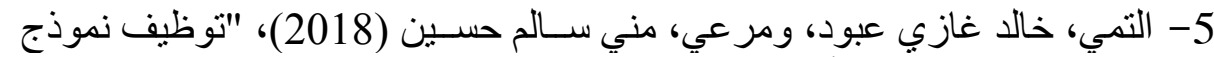
(SSBS)

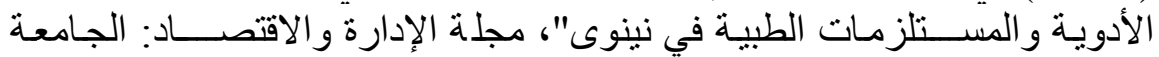

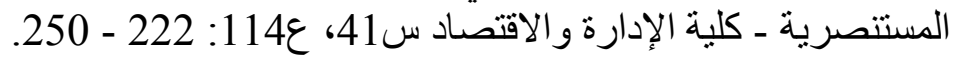

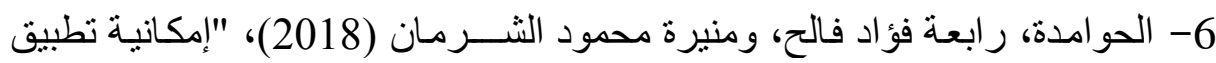

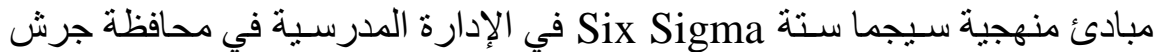

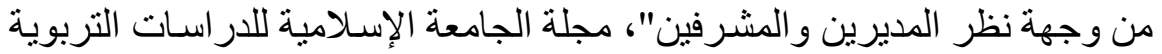

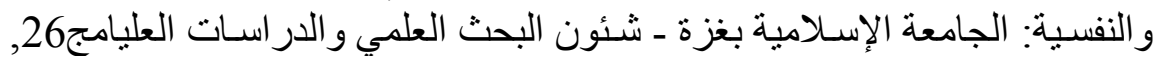

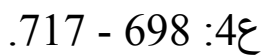

7- دبون، عبد القادر (2008)، 68 - 417 دور مداخل التكيف التكنولوجي في إدارة التغيير في المؤسسة، مجلة الباحث، جامعة ورقلة، العدد السادس.

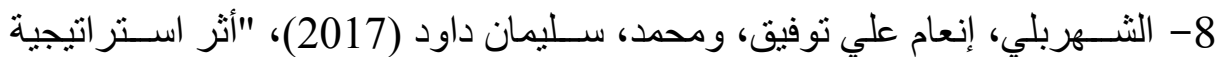

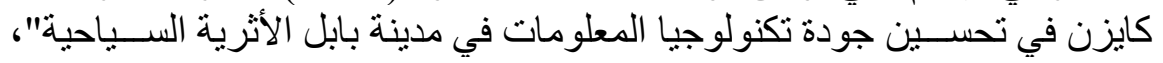

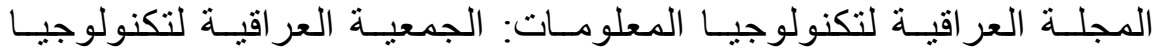

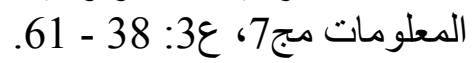

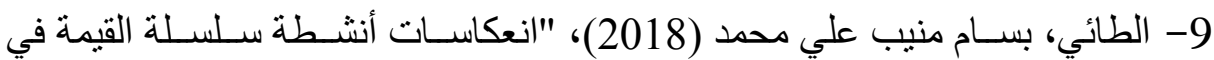

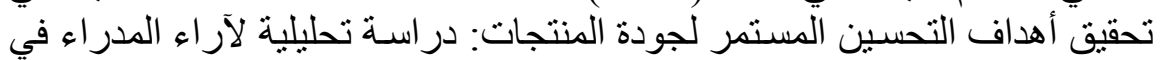

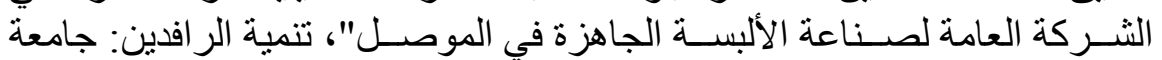

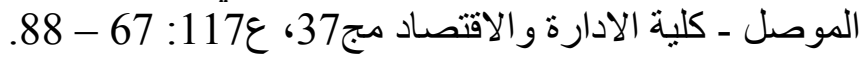

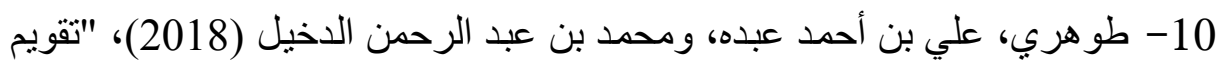

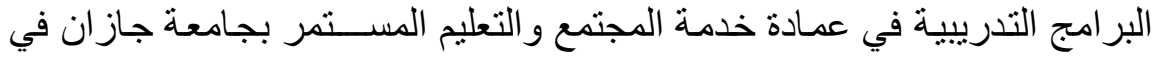




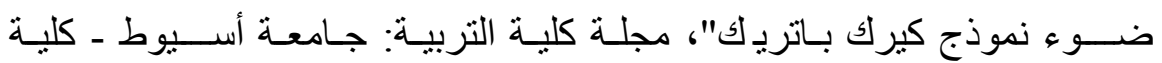
التربية مج34، ع2: 302 - 335.

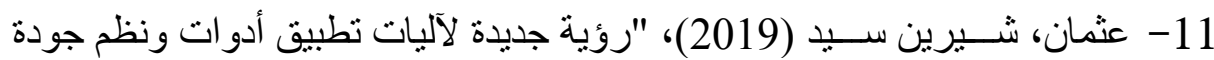

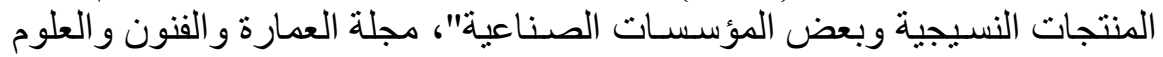
الإنسانية: الجمعية العربية للحضارة و الفنون الإسلامية عاعنية 13: 244 - 266.

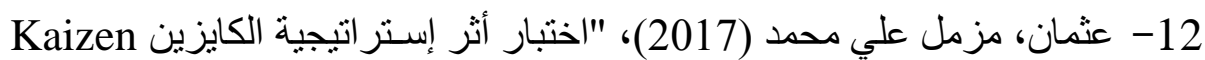

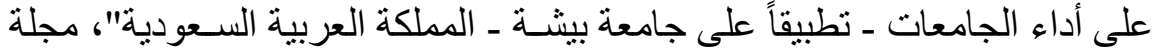

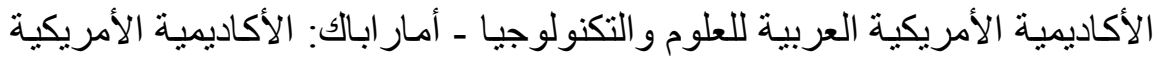

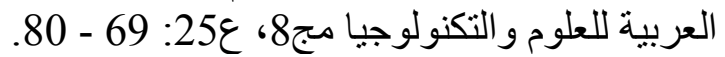

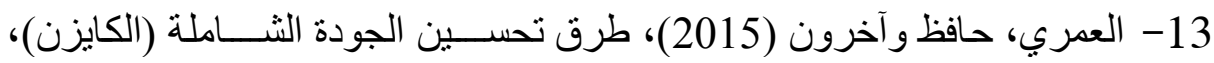
مكتبة شذر ات الالكترونية.

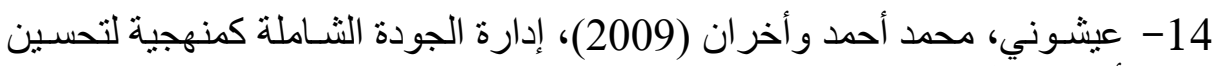

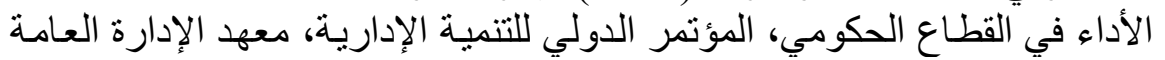

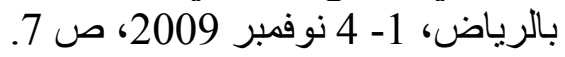

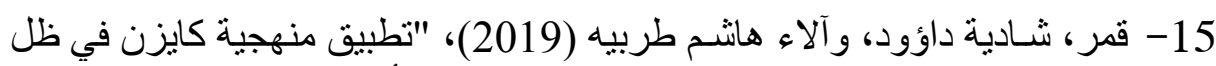

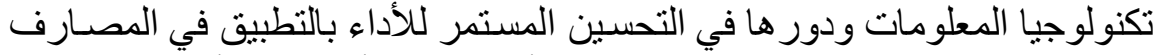

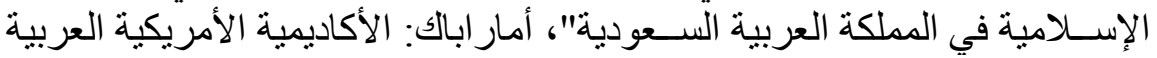

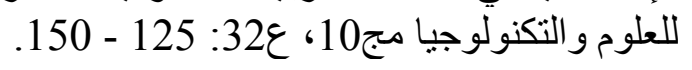

16- الكسر ، شـريفة بنت عوض (2018)، "نظرية كايزن و إمكانية تطبيقها في كلية

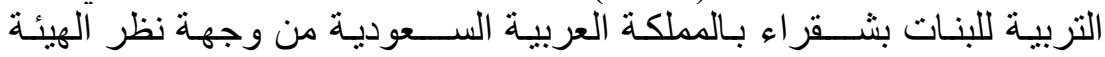

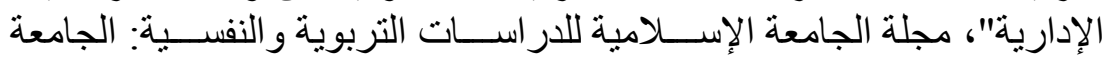
الإســلامية بغزة ـ شـئون البحث العلمي و الدر اســات العليا مج6، ع2: 154 ـ ـ

17- مصطفى، مصطفى عبد الستار (2017)، "دور التدريب كأحد عو امل التحسين

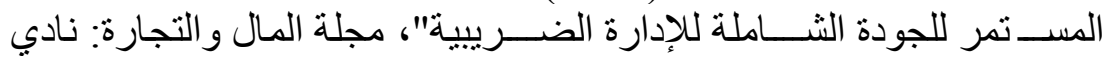

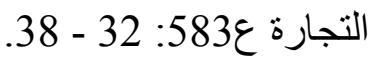

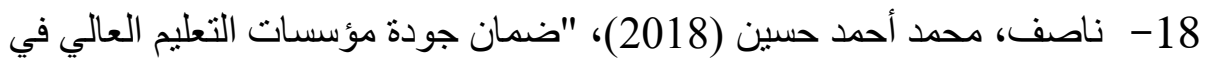

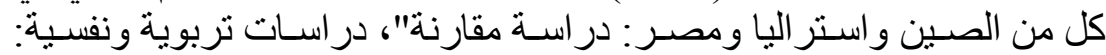
جامعة الزقازيق ـ كلية التربية ع99: 1 - 162.

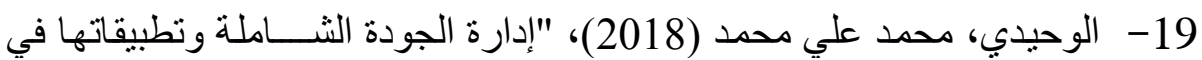

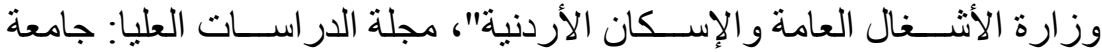

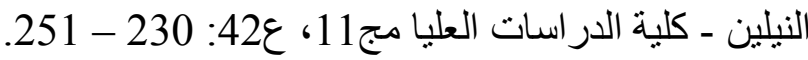




\section{References:}

1- Alhawat, A. Al-awami, M., \& Said, B. (2004), The march of Libyan higher education: achievements and ambitions. General syndication of University Staff Members, Tripoli.

2- Amit, K. A. \& Suraj, C. (2015), Assissing the application of Kaizen Principles in Indian smal-scale Industry, International Journal of Lean Six Sigma, 6 (4), pp 369-396.

3- Asaad, Mohd Norhasni Mohd, Rohaizah Saad, Rushami Zien Yusoff, (2005), 5S, Kaizen and Organization Performance: Examining the Relationship and Level of Implementation Using Rasch Model in Malaysian Automotive Company, International Academic Research Journal of Business and Technology 1(2) PP 214-226.

4- Avari, A., Zulkifli, N. \& Yusuff, F. M. (2011), Evaluation of approaches to strategy in Lean Manufacturing and safety management systems and clarification of the relationship between them, World Applied Sciences Journal, 15(1), pp 19-26.

5- Becker, J. E. (2001), Implementing 5S: to promote safety \& housekeeping, Professional safety, 46(8), pp 29-31.

6- Chapman, D. E. \& Gallagher, M. (2005), Clean House with lean 5S, Quality progress, 38(6), pp 27-32.

7- Dysko, D. (2012), GEMBA KAIEN: Utilization of human potential to achievement continuous improvement of company, The International Transport \& Logistics, Vol. 12, ISSN: 1451-107X, pp 42-64.

8- Feijoo, A., Ace-Farina, Suarez, R. Maceiras (2014), Improvement of Quality Management in Higher Education through KAIZEN 5S Technique, International Conference on Education and New Learning Technologies, ISSN: 23401117, pp 915-920.

9- Gratiela, Dana BOCA (2011), kaizen method in production management, International Scientific Conference Young Scientists. 
10- Imai, M., (2013), Gemba Kaizen: A Commonsense Approach to a Continuous Improvement Strategy, McGraw Hill, New York, Second Edition.

11- Jignesh A. Bhoi, Darshak A. Desai, Rohit M. Patel, (2014), The Concept \& Methodology of Kaizen A Review Paper, International Journal of Engineering Development and Research, Vol. 2, Issue 1, ISSN: 2321-9939.

12- Joshi, A. (2013), Implementation of Kaizen as a continuous improvement tool: A Case study, International Journal of Management Research and IT, ISSN: 2320-0065, pp 1-29.

13- Karkoszka, T., Honorowicz, J. (2009), Kaizen philosophy a manner of continuous improvement of processes and products, Journal of Achievements in Materials and Manufacturing Engineering 35/2. pp 197-203.

14- Keeley, E. J., (2004), Institutional research as the catalyst for the extent and effectiveness of knowledge-management practices in improving planning and decision-making in higher education organizations. Unpublished doctoral dissertation. Arizona: Northcentral University, [en ligne] disponibe sur sunzi.lib.hku.hk/ER/detail/hkul/3518550

15- Liuxing, Taso, P. L., Patrick Rau and Liang Ma, (2015), "development of a Quick Instrument Measuring Kaizen Culture (for Chinese)", Procedia Manufacturing, Vol. 3, pp 4703- 4715.

16- Manuel, F. S. B., Juan, R. P., \& Laoucine, K., (2011), Thoughts of Kaizen and its evaluation three different perspectives and guiding principles, international Journal of Lean Six Sigma, 2(4), pp 288-308.

17- Masaaki, Imai: Gemba Kaizen- A Commonsense Low cost Approach to Management New York, McGraw- Hill, 1997, pp 19-22.

18- Osterling, Mike, (2014), Lean Kaizen: A Simplified Approach to Process, Enna.com.

19- Randhawa, J. S., and Ahuja, I. S. (2017), "Evaluating impact of $5 \mathrm{~S}$ implementation on business performance", 
International Journal of Productivity and Performance Management, Vol. 66, No. 7, pp 948-978.

20- Sevtap, C., (2015), Development of a tool to measure the effectiveness of kaizen events within the wood products industry, Master of Science, the faculty of the Virginia polytechnic Institute and State university.

21- Swafy, A. \& Ghatass, B. (2003), Training Students in Business Institutions: Trail Analysis and Development Requirements. Arabic Congregation for Developing Management and Trade Facilities in the Arab Universities. Halab, Syria, 11-13 March.

22- Thalner, Deborah, (2005), The Practice of continuous Improvement in Higher Education, Western Michigan Leadership, USA, pp 15-38.

23- Thessaloniki, R., (2006), KAIZEN: Definition \& Principles in brief: A Concept \& Tool for employees in evolvement. www.michailolidis.gr.

24- Titu, M., Oprean, C. and Grecu, D. (2010), Applying the Kaizen Method and the 5S Technique in the Activity of Post-Sale Services in the Knowledge-Based Organization. The International Multi Conference of Engineers and Computer Scientists (3), Hong Kong.

25- Warwood, S. J., and Knowles, G. (2004), "An investigation into Japanese 5-S practice in UK industry", The TQM Magazine, Vol. 16, No. 5, pp 347-353. 